NBER WORKING PAPER SERIES

\title{
FDI AND CAPITAL FORMATION IN DEVELOPING ECONOMIES: NEW EVIDENCE FROM INDUSTRY-LEVEL DATA
}

\author{
Alessia A. Amighini \\ Margaret S. McMillan \\ Marco Sanfilippo \\ Working Paper 23049 \\ http://www.nber.org/papers/w23049 \\ NATIONAL BUREAU OF ECONOMIC RESEARCH \\ 1050 Massachusetts Avenue \\ Cambridge, MA 02138 \\ January 2017
}

We gratefully acknowledge the comments received from Andrea F. Presbitero, Farid Toubal, Amelia Santos-Paulino and participants in the IMF/CFD Conference on "Financing for Development", Geneva, April 2015, and the "Economics of Global Interactions" conference, Bari, September 2015, and the Second International Conference on New Structural Economics, Beijing, December, 2015, and the UNIDO Conference on "Quality FDI, Growth and Development", Vienna, September 2016. The views expressed herein are those of the authors and do not necessarily reflect the views of the National Bureau of Economic Research.

NBER working papers are circulated for discussion and comment purposes. They have not been peer-reviewed or been subject to the review by the NBER Board of Directors that accompanies official NBER publications.

(C) 2017 by Alessia A. Amighini, Margaret S. McMillan, and Marco Sanfilippo. All rights reserved. Short sections of text, not to exceed two paragraphs, may be quoted without explicit permission provided that full credit, including ()$^{\text {notice, }}$ is given to the source. 
FDI and Capital Formation in Developing Economies: New Evidence from Industry-level Data

Alessia A. Amighini, Margaret S. McMillan, and Marco Sanfilippo

NBER Working Paper No. 23049

January 2017

JEL No. F21,F23,F63

\begin{abstract}
We contribute to the long debated issue of whether inward foreign direct investment (FDI) can stimulate investment in developing countries by introducing a novel measure of FDI, based on industry-level data. Our results suggest a positive impact of FDI on total investment - measured as the ratio of gross fixed capital formation to GDP - but only if multinational enterprises engage in manufacturing production; the same does not hold for other business activities. Moreover, we find evidence of a more beneficial impact of foreign investors from advanced economies compared to developing ones. Our results are robust to alternative measures of FDI, as well as to instrumental variable approaches accounting for the potential endogeneity of FDI.
\end{abstract}

\author{
Alessia A. Amighini \\ Marco Sanfilippo \\ Associate professor \\ Department of Political Sciences \\ Department of Economics and Business \\ University of Bari \\ Università del Piemonte Orientale \\ Bari, Italy \\ Novara, Italy \\ alessiaamighini@gmail.com \\ Institute of Development Policy \\ and Management \\ University of Antwerp \\ Margaret S. McMillan \\ Antwerp, Belgium \\ Tufts University \\ Department of Economics \\ marco.sanfilippo@uantwerp.be \\ 114a Braker Hall \\ Medford, MA 02155 \\ and International Food Policy Research Institute \\ and also NBER \\ margaret.mcmillan@tufts.edu
}




\section{Introduction}

As economic growth is mostly driven by capital accumulation, at least up to the optimal level of capital per worker (Solow, 1956), increasing investment in developing countries is a key policy objective. In countries with persistently insufficient domestic capital formation, foreign direct investment (FDI) is often welcome as a means to financing development and has been a top policy priority, especially since the Monterrey Consensus of 2002. FDI attraction policies into the developing world have since then increased dramatically, so that FDI has actually become the leading source of external financing (Calderon et al, 2004; OECD, 2014): FDI in terms of stock tripled in Least Developed Countries (LDCs), Small Island Developing States (SIDS), and quadrupled in landlocked developing countries (LLDCs) (UNCTAD, 2015).

Theory suggests that FDI plays a crucial role in financing development, both directly, as an external source of capital, and indirectly through its impact on domestic capital formation. But the overall effects of FDI on economic growth in developing economies are far from certain, and contrasting perspectives on the developmental impact of FDI vividly confront with one another both in scholarly and in policy circles. In fact, FDI can potentially be either beneficial or detrimental to domestic investment. Theoretical prescriptions on which net effect a country hosting FDI should expect are still inconclusive, as evidenced by the sizeable literature on the effects of inward FDI on domestic investment, which dates back since at least the end of the 1970s (Brecher \& Diaz-Alejandro, 1977; Lall \& Streeten, 1977; Matos, 1977). No less controversial are the results from the empirical literature, which suffer from severe data limitations on foreign investment, because they rely upon aggregate FDI data taken from the Balance of Payments (BoP) statistics (not an appropriate source of foreign investment data for a number of reasons, as explained in Section 2).

Yet, empirically assessing the role of FDI in financing development - and possibly also the conditions under which FDI is likely to have beneficial or detrimental effects - has remarkable policy implications. Since economic policy can influence investment decisions, understanding whether and how FDI triggers more or less domestic investment would help tailoring investment policy measures aimed at attracting FDI. Those policies are now widespread in a growing number of developing countries, but largely unconditional on the actual activities performed by MNEs, and often combined with industrial development and fiscal policies towards domestic investment that are not necessarily consistent with the overall aim of raising capital formation.

This paper contributes to the long debated issue of whether inward FDI can stimulate domestic investment in developing countries in three main ways. First, 
we introduce a novel measure of FDI, based on investment-level data by multinational enterprises (MNEs) operating in developing countries, which allows overcoming the previous data limitations on real investment by MNEs and on the presence and weight of foreign firms in host economies. Most studies analyse the impact of FDI by expressing FDI as a percentage of gross fixed capital formation in the domestic economy. This ratio is often considered an indicator of the share of domestic capital formation undertaken by foreigners. However, the positive impact of foreign firms on domestic capital formation is not necessarily related to their initial investment size, but includes other factors, such as the number of interactions between any domestic firm and any foreign firm. In developing countries local firms may lack access to foreign markets and technology, and therefore suffer from "binding constraints" (Rodrik, 2006) to growth that inhibit their investment behaviour. The entry of MNEs could serve as a vehicle for domestic firms to get access to new technology and possibly also to larger foreign markets, to the extent that they can enter into arm's length relationships with more productive firms that can exploit larger international distribution networks, thereby increasing the profitability of domestic investment. According to Blalock and Gertler (2008), for instance, foreign firms have an incentive to widen the local network of suppliers, rather than concentrating on few suppliers, because this can induce competition among domestic firms and therefore reduce overall production costs and raise the quality of inputs. Evidence from a survey on a large number of MNEs based in 19 African countries (UNIDO, 2011) shows that the initial investment size is related neither to the number of linkages they establish with domestic suppliers nor to the size of total investment of foreign affiliates (Figure 1). From this perspective, the same amount or size of total MNEs' investment would have a different impact on GFCF depending on the actual number of foreign firms entering the host economy. This is why the number of foreign firms is a more appropriate measure than investment size, when assessing spillovers to the local economy (Lin and Saggi, 2005).

\section{FIGURE 1 HERE}

Second, we account for the possible differential impact of FDI on domestic investment according to 1) the business activities performed by MNEs abroad, distinguishing between manufacturing production and other business activities within the manufacturing sector (i.e. sales, marketing, client support, retail and wholesale) and 2) the source of FDI, distinguishing investing countries between advanced and developing economies. Our dependent variable varies by industry - as it is defined by the Gross Fixed Capital Formation (GFCF) for each 2-digit manufacturing industry - besides also being country and time variant. Therefore, we are able to explore the issue of whether FDI foster total investment in host economies in a much more refined way than in the extant literature (which focuses on the crowding in or out debate at the aggregate - i.e. national - level), by 
highlighting the sectorial heterogeneity of complementary and competitive effects due to the entry of foreign firms.

Finally, another important feature of this study compared to the extant literature is that we specifically focus on greenfield FDI, which imply an addition of fresh foreign capital, unlike mergers and acquisitions (M\&A), which instead represent just a change in the ownership structure of existing firms (Calderon et al., 2004; Ashraf and Herzer, 2014).

Our overall results suggest a positive impact of FDI on total investment. Moreover, we are able to better qualify the link between FDI and GFCF by identifying which types of FDI are more beneficial. Our evidence supports the widespread view that foreign capital can be a source of development financing for developing countries, but only if MNEs engage in productive activities, which exert spillovers to the host economies, and do not just engage in trade-related activities, which instead tend to remain enclaves without linkages to the domestic economy. We also find evidence of a differential impact of the presence of foreign firms from advanced countries compared to those from developing economies. The latter do not seem to have positive effects on total investment, and this is probably due to the shorter time since their entry and to stronger direct competition with domestic firms. Last but not least, we find that the positive impact of FDI on total investment does not necessarily imply a crowding in effect on domestic investment. Our results are robust to the adoption of alternative specifications, as well as after controlling for the potential endogeneity of FDI. More specifically, we address the potential endogeneity of FDI exploiting the exogenous variation of the distribution of outward FDI from the world's top investors by industry, assuming that this is correlated with the probability that FDI in a given industry has no direct influence on the investment performance of that industry.

The remainder of this paper is organized as follows. Section 2 outlines the related theoretical and empirical literature. Section 3 describes the data and the methodology. Sections 4 and 5 present the results. Policy implications and concluding remarks are in Section 6.

\section{Literature background}

Economic theory points to a number of distinct channels through which FDI may affect capital accumulation in recipient economies. FDI can exert both direct and indirect effects on overall capital formation. As regards direct effects, the most common view considers FDI as a financial flow contributing to capital stock accumulation, by adding up to domestic investment. As such, the impact of FDI largely depends on the entry mode of MNEs. Greenfield investments - i.e. brand new domestic subsidiaries of foreign firms - have a direct impact on capital 
formation as they create new capital assets, whereas M\&As are a partial or total transfer of existing capital assets through a change in the nationality of existing domestic firms, but do not add to the capital stock. Nor is it certain that the acquisition of a domestic firm by a foreign firm would lead to more investment than the acquired firm would have made without the acquisition (Mencinger, 2003; Agosin \& Machado, 2005; Herzer, 2012). ${ }^{1}$

Although the literature has regularly acknowledged a differential impact of FDI on capital formation depending on the entry mode of MNEs, most empirical studies rely on macro data that cannot disentangle between different entry modes. Only recently, Ashraf \& Herzer (2014) have explored the different impact of greenfield investment and M\&A on domestic investment, with aggregate data from UNCTAD; their results confirm that M\&A do not have a significant impact on domestic investment, whereas (estimated) greenfield flows report a positive effect, even if this seems to happen at the cost of domestic investors (crowding-out effect).

The literature has also invariably overlooked the fact that FDI as an aggregate measure from the BoP statistics represents just a financing flow, and not necessarily investment (Calderon et al, 2004). FDI includes any financial transfers from a multinational's headquarters to its subsidiary, and back ${ }^{2}$. As they are measured in net terms, aggregate FDI flows can be either positive or negative, but that does not relate at all to the amount of investment in the host economy. Moreover, aggregate FDI statistics do not allow for industry-level breakdown on a bilateral basis, nor include information about different entry modes of MNEs into foreign markets. All in all, such broad FDI statistics do not allow exploring the potential complementarities between domestic and foreign investments, calling for more disaggregated analysis (Arndt et al., 2009).

A complementary view is to look at FDI as knowledge flows brought about by foreign investment flows. FDI are often welcome in developing countries as they bring fresh capital together with a number of intangible assets that are usually scarce in those economies, namely technological capabilities, management skills, brand names, channels for marketing products internationally, product design (Romer, 1992; Moran, 2011).

Besides the direct effects of FDI on capital accumulation in the host economy, indirect effects can take place through the impact of foreign capital on domestic

\footnotetext{
${ }^{1}$ As a matter of fact, the increased importance of M\&A in total FDI flows starting in the 1990s, especially in developing countries embarking in massive privatisation policies, has been singled out as the likely cause of an observed weakening in the empirical FDI-investment link in that decade (World Bank 2001).

${ }^{2}$ UNCTAD (2013) claims that the amount of repatriated profits could be substantial, especially in certain sectors and countries. The same report estimates that, globally, in 2010 about $60 \%$ of total FDI income was repatriated.
} 
capital formation, as the entry of foreign firms may alter the incentives to invest by domestic firms. Several channels are at work.

Theory has pointed out a number of mechanisms through which FDI can increase the profitability of domestic investment. First, FDI can act as a catalyst for domestic investment because multinationals usually have greater access to information and financial resources than most private investors do in developing countries. Hence, they are able to both identify and take advantage of profitable opportunities more quickly than domestic investors, so that the entry of foreign firms in a developing country signals the existence of unexploited profitable business opportunities that domestic investors might not be capable of identifying or willing to seize by themselves. Moreover, foreign firms entering a developing country often bring about the need for more efficient infrastructure facilities (roads, telecommunications, ports, railways, etc.), which they can also contribute to finance (Cardoso \& Dornbusch, 1988). As poor or insufficient infrastructure is often a binding constraint to business development in developing countries, improved infrastructure can open up new business opportunities that would not have been profitable otherwise, thus increasing the profitability of overall domestic investment. A further mechanism through which foreign firms can contribute to capital formation is through the supply of scarce inputs (Helleiner, 1988), which they can vehicle by importing human and physical capital, technology, and other intangible assets. In particular, positive externalities are the increased availability of training services, managerial skills, technological capabilities, access to overseas markets, market information, all of which benefit domestic firms (Moran, 2011). The entry of foreign firms may also create new demand for inputs that can be supplied by local firms through backward linkages as complements to those imported from their home countries (Gorg and Greenaway, 2004). Finally, in developing countries with poor business opportunities, FDI can contribute with additional tax revenue invested in public goods (Cardoso and Dornbusch, 1988).

The literature has also emphasized the existence of potential negative effects on the profitability of domestic investment due to the presence of foreign firms. Different mechanisms may be at work. Foreign owned firms can acquire domestic market shares to the detriment of domestic firms (Aitken \& Harrison, 1999). Foreign firms can crowd out domestic investment if they increase the host country's interest rate by borrowing on the domestic market (Harrison \& McMillan, 2003). Foreign firms entering a developing country in sectors with relatively underdeveloped productive capacity may sensibly increase the cost of locally supplied inputs, especially wages (Lall \& Streeten, 1977). Moreover, FDI have uncertain effects on the degree of competition in host economies, as foreign firms, usually more efficient and productive than domestic firms, can boost competition among the latter, but at the same time could acquire market power, 
with a potentially negative effect on domestic investment (Markusen and Venables, 1999). FDI can have negative effects on overall capital formation in developing countries, when the entry of foreign-owned firms pushes the less efficient domestic firms out of the market and therefore reduces domestic production capacity (Gorg and Greenaway, 2004). Finally, foreign firms could also have a negative impact on the demand for local inputs, if they rely less on domestic inputs than domestic firms (Rodriguez-Clare, 1996).

Empirical evidence on the relation between FDI and investment has been mainly provided at the macroeconomic level ${ }^{3}$ (a summary of empirical evidence is reported in Table A1 in the Appendix). Macroeconomic studies typically use aggregate measures of investment to study either one particular country or a panel of countries. Among the first to analyse panels of countries, Fry (1993) used macroeconomic data for a sample of 16 countries to show that FDI can have a positive or a negative impact on domestic investment depending on the level of trade barriers and financial regulations imposed by the host country. Subsequent evidence is similarly inconclusive. Morrissey and Udomkerdmongkol (2012), Mutenyo, Asmah, and Kalio (2010) and Titarenko (2005) all find that increases in FDI crowd out domestic investment. Conversely, other scholars find that FDI crowd in private domestic investment, such as De Gregorio, \& Lee (1998), Bosworth \& Collins (1999), de Mello (1999), Borensztein, Ndikumana \& Verick (2008), Tang, Selvanathan, \& Selvanathan, 2008), Ramirez (2011), Al-Sadig (2013), Farla et al. (2014). Several scholars find mixed evidence when using several lags for FDI or when splitting the country sample according to geographic regions (Agosin \& Mayer, 2000; Misun \& Tomsik, 2002; Agosin \& Machado, 2005; Apergis, Katrakilidis, \& Tabakis, 2006; Adams, 2009), or even find no effect of FDI on domestic investment (Lipsey, 2000).

Overall, neither theory nor evidence provides a definitive answer as to the impact of FDI on GFCF. On balance, however, empirical studies seem to suggest that FDI has a positive impact on overall fixed investment. Arguably, none of the existing studies has been able so far to move behind the aggregate picture, ignoring the potential heterogeneity that can arise from micro factors such as the sectorial distribution of investors as well as the kind of business activity they perform. This papers aims at specifically filling this gap.

\footnotetext{
${ }^{3}$ Microeconomic studies are much less frequent. They include case studies and studies on firmlevel panel data for specific countries. Among those, Aitken and Harrison (1999), on a panel of more than 4,000 Venezuelan firms, show that the impact of FDI on domestic investment depends on the ownership structure. FDI that participates with domestic firms in a joint venture arrangement enhances the profitability of the domestic investment. By contrast, FDI negatively affects the productivity of firms with $100 \%$ domestic ownership. On balance, they find that FDI has a positive impact on domestic investment.
} 


\section{Data and Methodology}

Some studies have constructed a measure of GFCF net of FDI flows to try building a 'pure' measure of domestic investment (Morrisey and Udonmkerdmongkol, 2012). This approach has raised criticisms based on two main arguments. First, GFCF and FDI are measured according to different accounting rules (National Accounting rules and Balance of Payments, respectively) and are therefore hardly comparable in practice (Agosin and Machado, 2005). Second, and more fundamental, FDI flows from the BoP do not correspond directly to any measure of real investment. Indeed, as reported by Leino and Ali-Yrkko (2014: 3): “... real investments of foreign-owned companies can be funded locally or by other foreign entities than direct investors. (...). Furthermore, recorded inward FDI may consist of funds that are immediately invested abroad by the investment-receiving FDI enterprises".

\subsection{Descriptive statistics}

As in most of the studies listed in Table A1, we describe a traditional investment function but instead measure industry level GFCF in percentage over total GDP as our dependent variable. More specifically, we test the horizontal spillover of FDI at the industry level, i.e. whether MNEs entering a country in a given industry exert a positive or negative impact on total investment in the same industry. As foreign firms can stimulate spillovers both within and across sectors (through backward and forward linkages), our empirical specification is likely to underestimate the overall impact of FDI on capital accumulation in host economies ${ }^{4}$.

We collect sector data from the 2014 edition of the Industrial Statistical Database (INDSTAT) published by the United Nations Industrial Development Organization (UNIDO). INDSTAT provides information over the main aggregates, including $\mathrm{GFCF}^{5}$, for all manufacturing industries (defined at the 2-digit levels of the ISIC rev. 3) for a long time series (1964-2011) with full country coverage ${ }^{6}$. By looking only at manufacturing sectors (i.e. excluding natural resources and services), we provide a more precise picture of the potential effects of FDI on domestic investment. Unlike manufacturing FDI, FDI in natural resource sectors have a large share of their profits repatriated, rather than reinvested, as recently

\footnotetext{
${ }^{4}$ Due to the large sample of countries included in our study it has not been possible to find consistent information on input-output tables to explore the potential vertical spillovers of FDI on the GFCF of related industries.

${ }^{5}$ A detailed definition of how GFCF is measured in INDSTAT is provided in Appendix B.

${ }^{6}$ Since INDSTAT provides price indices for indexes for all the industries, we use those as deflators for GFCF, value added and FDI flows.
} 
estimated by UNCTAD (2013). On the other hand, FDI in services sectors generally require lower fixed investments.

Our sample includes all the countries not classified as high-income OECD by the World Bank definition based on their levels of per capita GNI in 2006. As industry level information for a number of (mainly low-income) countries included in INDSTAT presents a large number of gaps, ${ }^{7}$ our final sample consists of an unbalanced panel including 53 countries, listed in Table A2 in the Appendix.

As regards our main variable of interest, i.e. FDI, we rely on investment project level data from Financial Markets' FDIMarkets, which collects data on greenfield investments at the deal level, providing information on source country, destination country, industry (2-digit ISIC rev. 3) and year (2003-2011, the longest time series currently available). Summary statistics on the number of FDI projects by industry in the 53 developing countries covered by our analysis are shown in Table $1^{8}$.

\section{TABLE 1 HERE}

Our main research question is to understand the impact of foreign firms on overall capital formation in host economies. We exploit the richness of our industry-level data to build two alternative measures of FDI: 1) the number of MNEs entering a host economy in a given country/industry/year combination (henceforth called "flows") or 2) the total number of MNEs operating in a host economy since the beginning of the period considered (cumulated FDI or FDI "stock"). ${ }^{9}$

Using industry level FDI data is an important innovation compared to using aggregate evidence. In fact, the net impact of FDI on capital accumulation is likely to depend positively on the degree of sectorial heterogeneity. Agosin and Machado (2005), for instance, suggest that FDI is more likely to add up to GFCF in sectors with lower investments and replace it in larger industries. A further innovation on the previous literature is the possibility to distinguish among the business activities undertaken by foreign firms (see Figure 2). For each deal, FDIMarkets

\footnotetext{
7 When cleaning the data, individual country-sector pairs reporting abnormal values of GFCF on GDP (e.g. over 100\%) have been dropped. We have also excluded four countries (Indonesia, Iran, Madagascar and Vietnam) whose values of GFCF on GDP were unusually high (between 40 and $80 \%$ for each of the reported industries), making the total greater than $100 \%$.

${ }^{8}$ The list of FDI included in our study is not as large as the entire FDI database, but it depends on data availability in INDSTAT. In fact, the number of observations is the number of investments in any given developing country, conditional upon that country being covered by INDSTAT with industry level data in any of the $\mathrm{N}$ manufacturing industries in any given year between 2003 and 2011.

${ }^{9}$ In the remainder of the paper, we also compute alternative measures of FDI as robustness checks, including the share of foreign affiliates on the total number of firms in each industry and the total flows.
} 
includes a description of the activity performed by each foreign firm in the host economy. This allows identifying which foreign firms engage in manufacturing production, compared to those that only engage in other business activities within manufacturing sectors (such as marketing and sales) with no production facilities in the host economy. Drawing on the large literature on FDI and development, we can argue that the potential spillovers to the domestic economy, including on total investment, largely depend on the extent to which foreign investors are involved in activities that are more likely to foster local linkages, such as production, rather than "footloose" activities, such as export platform or quota-hopping FDI (Farole and Winkler, 2013).

\section{FIGURE 2 HERE}

Finally, we further innovate on the previous literature by accounting for the origin of FDI. There is nowadays a rising interest in understanding whether South-South FDI could result in larger positive spillovers compared to North-South flows, but still little evidence playing in favour of this hypothesis (Amighini and Sanfilippo, 2014), and evidence is still scant and inconclusive about the potential effect of South-South FDI on domestic capital formation. The underlying idea is that FDI might have a different impact on domestic firms depending on the technological, geographic or institutional "distance" between home and host economies. Southern economies are more likely to share similar technologies due to similar factor endowments, and to higher complementarities along the product space (Klinger, 2009; Hausmann et al., 2007). While these arguments have often been raised in favour of stronger spillovers from South-South FDI, they might as well support the claim that Southern MNEs might be stronger competitors to domestic firms (Sanfilippo and Seric, 2016) ${ }^{10}$.

\subsection{Methodology}

We start with a basic specification to identify the relation between FDI and GFCF:

$$
G F C F_{i x t}=\beta_{1} F D I_{i x t}+\gamma_{i}+\theta_{x}+\delta_{t}+\varepsilon_{i x t}
$$

where the dependent variable is GFCF in country $i$, industry $x$, and year $t$ measured as a share of total GDP. Our main control variable, FDI, is the number of investments received by country $i$ in industry $x$ in year $t . \gamma_{i}, \theta_{x}$ and $\delta_{t}$ are country, industry and year fixed effects, respectively.

\footnotetext{
10 Following the theoretical model by Ghebrihiwet and Motchenkova (2015), competition is a less compelling argument in the case of Northern MNEs. Due to the higher cost of technology transfer in developing countries, Northern MNEs transfer fewer resources to their affiliates, making it less likely that they crowd-out domestic firms.
} 
In further specifications of (1) the FDI variable is disaggregated according to the business activity performed and the investors origins (separately, due to the high correlation between the two variables), as follows:

$$
\begin{aligned}
& G F C F_{i x t}=\beta_{1} F D I_{-} P R O D_{i x t}+\beta_{2} F D I_{-} T R A D E_{i x t}+\gamma_{i}+\theta_{x}+\delta_{t}+\varepsilon_{i x t} \\
& G F C F_{i x t}=\beta_{1} F D I_{-} N O R T H_{i x t}+\gamma_{i}+\theta_{x}+\delta_{t}+\varepsilon_{i x t} \\
& G F C F_{i x t}=\beta_{1} F D I_{-} S O U T H_{i x t}+\gamma_{i}+\theta_{x}+\delta_{t}+\varepsilon_{i x t}
\end{aligned}
$$

A count measure for FDI, rather than flows, should partly reduce the endogeneity problem on the FDI variables; we exclude at least the possibility that the initial amount invested - the purchase of fixed assets - could end up being part of GFCF (which is a major concern in the case of greenfield FDI). Still, the correct identification of the relation between FDI and GFCF poses a number of econometric challenges, including those related to the direction of causality and the omitted variables bias. Theory suggests a potential reverse causality between GFCF and FDI, since higher domestic investments could play as a signal to foreign firms, in turn affecting their entry choice (Mody and Murshid, 2005). At the same time, local conditions that influence domestic investment may in turn affect the decision to invest by foreign multinationals.

In the remainder of the paper, we adopt different strategies to tackle the potential endogeneity of our main control variable, while testing at the same time the robustness of our estimates. First, we control for different combinations of country, industry and year effects in the main specification and in robustness checks, to account for all the possible unobserved factors and omitted variables that could influence domestic and foreign investment decisions. In successive specifications, we also include a number of controls at both the country- and country-industry level. Second, we run our basic regression including different lags of the FDI variable, to tackle the potential simultaneity bias. Third, we adopt the most traditional approaches tackling endogeneity directly by means of instrumental variables. Table 2 provides summary statistics and variables description is reported in table $\mathrm{A} 3$ in the appendix.

\section{TABLE 2 HERE}

\section{Results}

The main results from our basic identification strategy as described in (1)-(4) are reported in Table 3. 


\section{TABLE 3 HERE}

By looking at the number of investors, rather than flows, we take a broader look at FDI as more than the amount of capital invested, also considering the knowledge flows that accompany capital. The $\beta$ coefficients' size from regressions with a count variable for FDI (FDI_N) should be interpreted as the impact on GFCF of any additional foreign firm entering a given host country in the form of greenfield FDI. This measure does not account for the direct effect of investment size (which in the case of greenfield FDI involves a direct contribution to GFCF due to purchase of fixed assets), but rather considers the overall contribution of foreign multinationals to total investment (which can show up in alternative ways, regardless of the size of the initial investment) ${ }^{11}$.

As what we test is a relation between total investment and the number of FDI (n_FDI), a $\beta$ coefficient greater than 0 confirms that FDI has an overall positive effect on total investment (GFCF). Our estimated coefficient is about 0.002, meaning that the entry of an additional foreign investor will result in an increase of about 0.002 percentage points in the GFCF/GDP ratio. Despite the small coefficient size, its economic relevance is pretty high. A one standard deviation increase in the number of foreign firms (i.e. slightly over 10 firms) entering a given country-industry pair raises the GFCF/GDP ratio by about 0.018 percentage points, i.e. a $30 \%$ increase from its average. Interestingly, this positive relation is also robust to the adoption of the "stock" (i.e. cumulative flows of FDI between 2003 and 2011) of foreign companies in the host country as a measure of FDI (columns 1 and 4 of Table 3 ). It should be noticed that this is high in relative terms, but corresponds to low increases in the GFCF/GDP ratio in absolute terms.

Additional findings show that the type of activity performed by foreign firms matters to determine the net effect of FDI on GFCF. Foreign affiliates engaged in productive activities are more likely to raise the profitability of domestic investment, unlike those operating in trade-related activities. In our view, this is a relevant distinction, especially in a context where most FDI are strategically linked to different stages of global value chains (GVCs). In this regard, our results suggest that foreign affiliates involved in local production are more likely to contribute to GFCF, because the propensity to invest in middle stages of the value chain is higher compared to investments in upstream or downstream activities, where investment income is less likely to be reinvested (UNCTAD, 2013). In addition, production-oriented FDI are more likely to generate domestic spillovers in the

\footnotetext{
11 Evidence reported in Agosin and Machado (2005: 152) suggests that the initial purchase of fixed assets by foreign firms (i.e. what enters in the balance of payment definition of FDI) represents only a small fraction of foreign firms' total outward investment, which subsequently includes assets for modernization and technology upgrading.
} 
form of backward and forward linkages ${ }^{12}$ (Rodriguez-Clare, 1996). Conversely, foreign investments in non-productive activities do not seem to exert a positive impact on domestic investment, because they mainly aim to create platforms either for exports to third countries or for imports from the investing country that can not only outperform domestic activities (up to the extent they stop investing or exit the market), but also not contributing to generate any new investments. In both cases, foreign firms that are only involved in non-productive activities in host economies tend to have more direct relations with parent firms (intra-firm transactions), and rely less on market-based transactions with local firms.

Finally, a further important dimension that we are able to explore with our data is the different effects of FDI according to the origin of the investor. Differently from our ex-ante expectations, our results do not support the view that emerging and developing countries investors have so far contributed to raise GFCF in developing economies. Conversely, we find that a positive and significant relation characterizes FDI from advanced economies in a persistent way.

The explanations for the lack of effects of South FDI can be diverse. First, a scale effect might be at work. Southern FDI are still fewer (in terms of number of projects at least, as they still represent less than $20 \%$ of the total) than Northern ones. Second, Southern firms are relatively younger and investors less structured and experienced compared to their Northern counterparts. These features are particularly relevant when looking at their impact on total investment. Investments are lumpy, and therefore risky, requiring knowledge of the host country and experience that Southern MNEs are still building up starting from lower levels (Cuervo-Cazurra and Genc, 2008). Third, the negative effect can result from a competitive effect. Contrary to Northern MNEs, Southern MNEs adopt technologies that are more adapted to the local market, so that they may find themselves in direct competition with domestic firms, crowding them out of the market, and discouraging their propensity to invest. On this regard, it is worth noticing that there might also be a divergence between short- and long-run effects of FDI on local investment. For example, De Backer and Sleuwaegen (2003) show that FDI displaces local investment by Belgian manufacturing companies in the short run, but in the long run this effect is limited or even reversed.

\subsection{Main results with additional controls}

\footnotetext{
${ }^{12}$ Considering the level of industry disaggregation in our data, we can still consider within-sector linkages as a main potential source of FDI spillovers. According to many available I/O, most of the 2-digit industries in manufacturing sectors (including textiles; wood; motor vehicles; chemicals) source most of their inputs from the same industry and sell most of their output to the same industry (see WIOD website: http://www.wiod.org/new_site/database/wiots.htm)
} 
Following the theoretical insights and previous empirical works, we augment (1)(4) by including a number of control variables to account for factors that could potentially affect GFCF. More specifically, we add GDP growth to account for the fact that current investment decisions depend on the expected flow of future profits, which are increasing in income; political stability and inflation are measures of political and economic uncertainty surrounding investors. We also include some industry specific variables, taken from INDSTAT, such as the size and the value added produced. As shown in Table 4, the coefficients of the FDI variables are not affected by the introduction of additional country- and countryindustry controls.

All the country-level variables have the expected sign, although not statistically significant. This is not surprising, considering our dependent variable is measured at the country-industry level, and the effect of such factors might therefore be heterogeneous across industries. In addition, the lack of significance for some of these variables is coherent with the previous evidence, such as the case of good governance (Farla et al., 2014), or the relation between the cost of capital and domestic investment (Mody and Murshid, 2005).

\section{TABLE 4 HERE}

As for as the variables taken from INDSTAT, our results show that capital formation in host economies is not independent from the characteristics of the receiving industry, and this is consistent across different specifications. In particular, the overall amount of investment depends on the size of the industry, proxied by the total employment ${ }^{13}$. In addition, the impact on capital formation is higher, the higher the capacity of the host industry to generate value added.

\section{Additional results and robustness checks}

In the remainder of this section, we present a number of robustness checks that test the stability of our model to different measurement of the FDI variables (section 5.2.1) and accounting for the potential endogeneity of the GFCF-FDI relation (5.2.2).

\footnotetext{
${ }^{13}$ Results do not change if we use the total number of domestic firms net of the number of foreignowned firms instead of the total employees. This, however, does not exclude the presence of foreign firms in the data, due to the inclusions of investors established before 2003 or through different modalities, i.e. M\&As.
} 


\subsection{Alternative measures of FDI}

We enrich our analysis by also testing the relation between investment flows and total investment, the traditional approach followed by the vast majority of the studies reported in Table A1, within the crowding-in/out debate. As FDIMarkets reports the capital expenditure for each project, based on the initial investment announced at the time of entry, we can compute investment flows at the host country and industry level. One caveat is that large portion of these data is estimated based on a proprietary econometric model, introducing measurement errors in the data. Specific to our sample of developing countries' recipients, this affects about $64 \%$ of the projects included ${ }^{14}$. Still, however, when looking at some descriptive statistics, we can see that the total value computed from FDIMarkets behave quite similarly compared with both the more reliable information on the number of projects and with other aggregate statistics based on Balance of Payment information, such as those provided by UNCTAD ${ }^{15}$ (see Figure 3).

\section{FIGURE 3 HERE}

Table 5 reports the results of model (1) where FDI are measured in terms of investment flows rather than number of foreign firms. As we are testing a relation between foreign investment size and total investment (as percentage of GDP), the coefficients' size should be interpreted as the impact on GFCF/GDP of one dollar of FDI entering a given host country in the form of greenfield FDI. Our estimated coefficients are still mostly positive, which confirms the net positive effect of FDI. In particular, a one standard deviation increase in FDI flows (i.e. around $521 \mathrm{mln}$ $\$$, due to an average increase in the number of foreign firms by over 10 , each of which invests on average $48 \mathrm{mln} \$$ ) generates around 4 bln $\$$ increase in GFCF. Again, we do not find any significant relation between investment flows and GFCF for FDI with no production activities and for Southern FDI 16.

\section{TABLE 5 HERE}

As an additional robustness check related to the measurement of FDI, we have also run the main regression using the share of foreign plants on the total number of

\footnotetext{
${ }^{14}$ It should be noticed that these are the data on which UNCTAD compiles the annual World Investment Report, and adopted in empirical research by other scholars (e.g. Davies and Desbordes, 2015). In addition, in our specific case, data on the constructed flows is highly correlated to the data on the number of firms.

${ }^{15}$ When comparing the flows computed using FDIMarkets data with UNCTAD statistics it must be noted that the former represents only a fraction of the latter, since they do not include M\&As, as well as other recorded components of FDI including for instance reinvested earnings.

16 The coefficients on FDI with no-productive activities in column 2 are extremely high. This is due to the very low values of that variable, on average representing less than $0.001 \%$ of total GDP. This means that should the FDI/GDP ratio go up by 1 percentage point (i.e. by $0.001 \%$ to $1.001 \%$ of GDP), the corresponding drop in GFCF on GDP could be substantial.
} 
firms in each industry (computed net of the stock of investment). Results, reported in Table A4 in the appendix, look similar to those in table 3, confirming a positive effect of FDI, also in relative terms. Despite results are consistent also in this case, however, we cannot exclude that a relative measure of FDI share is biased, considering the lack of M\&As from the overall count.

\subsection{Controlling for endogeneity}

As discussed in section 3.2, endogeneity due to omitted variables and reverse causality is a potential issue in our model, which we try to tackle in different ways.

First, to deal with omitted variables, we have checked the stability of the coefficients of our main specifications to different combinations of fixed effects. Specifically, Table A5 shows that the results are highly stable to specifications using country-industry and year-effects (columns 1-4) as well as country-year and industry-year effects (columns 5-8).

Second, to deal with the potential reverse causality of FDI and GFCF we have checked whether results are robust to the inclusion of various lags of the FDI variables. Table A6 reports the results including the first three lags of FDI and seem to show that the effect of FDI on GFCF is persistent, and does not change significantly compared to the case in which the variable is set at time $t$.

\subsubsection{Instrumental Variables (IV) approach}

A first, traditional, strategy to address the potential endogeneity of the FDI variable is to find valid external instruments, i.e. variables that are correlated with the regressor but not directly affecting the dependent variable. The difficulties in finding out some good instruments in this specific setting are well exemplified by the existing literature, quoted in Table A1, which has so far addressed the potential endogeneity of FDI by adopting a dynamic panel framework, i.e. one in which instruments are exploited from within the model (see also the section 5.2.2). An exception is the paper by Delgado and McCloud (2014), in which the authors use an average of four variables (economic growth; exchange rate; interest rate and saving rate) for the top trade partners as instruments for both the inward and outward FDI of a given country. We depart from this and consider the average economic growth and the exchange rate of the top three investors in each of the country in our sample as potential instruments to be used in our IV regression. A faster economic growth at home is normally found to be a determinant of FDI decision, as it is in the case of a favourable exchange rate, which can push firms to invest abroad influencing their relative wealth (Alfaro et al., 2004; Yeaple and Keller, 2009). In addition, we consider also a variable reporting the total amount of FDI flows by the top ten source countries to the nonOECD recipients using UNCTAD FDI statistics, weighted by the distance to the host 
country ${ }^{17}$. Using total investments by the larger sources in absolute terms, rather than from the main partner countries, should reduce the risk of finding cases in which a large part of the total investment from one country represents almost the total of the FDI received by a specific partner in a given industry. On the other hand, the total flows by the top world sources should not be related to the domestic investment in a given country-industry.

Still, however, being these aggregate measures, the risk is that they can be weakly correlated to our FDI variable, which is instead computed at the country- and industry- level. Finding an instrument available at the industry level is, however, even more challenging. Some existing work used sectorial targeting by investment promotion agencies (Harding and Javorcik, 2012; Alfaro and Charlton, 2013; Farole and Winckler, 2013), but unfortunately this information is not available for all the countries and periods covered by this study (besides being potentially correlated to the levels of domestic investments, due to self-selection of better performing industries in targeting) ${ }^{18}$.

We thus try to construct a country-industry specific instrument exploiting the information available in our original FDI database. More specifically, along the lines of Jordaan (2011), we build an instrument representing the industry's share of the total number of FDI by the top source countries directed to the group of non-OECD recipients. As emphasized by Jordaan (2011), independently on the host economy, there are some industries that are more likely to receive FDI and this underlying distribution, while being potentially related to the observed distribution of FDI projects, should not affect the size of domestic investment in a given country-industry pair.

Table 6 reports the results of the first and the second stage regressions based on a 2SLS IV method with the inclusion of country, industry and year fixed effects. We try different combinations of instruments to check the stability of the results. From the first stage regression we notice that the industry share of FDI is significantly, correlated with the total number of projects by the top investors in the same industry. A weaker relation is found between our variable of interest and the other external instruments, especially growth, likely to be conditioned by the aggregate nature of these variables.

TABLE 6 HERE

\footnotetext{
17 Based on FDIMarkets data, the top ten source countries in non-OECD markets are, in order, the US, Germany, United Kingdom, Japan, France, Spain, Italy, the Netherlands, Switzerland and India. 18 Also trade variables, such as applied tariffs (as in Yeaple and Keller, 2009) or exports and imports with major trading partners, have the advantage of being reported at the industry level and of having an influence on FDI, but are also likely to affect domestic economic conditions, including GFCF.
} 
Overall, results of the second stage regression show that there is a positive and significant effect of FDI on GFCF even after accounting directly for the potential endogeneity of the former variable, confirming once again the robustness of our main result. We test the performance of the instrumental variable approaches by means of the Hansen test of overidentification. All over the different specifications adopted the tests suggest that the instruments are generally valid and well performing.

\subsubsection{Dynamic panel model}

As a final step, and along the lines of the vast majority of the existing empirical literature reviewed in Table A1, we estimate our model by means of a dynamic panel based on a two-step system GMM estimator (Blundell and Bond, 1998; Roodman, 2009). A dynamic panel has two main advantages in the context of our data. The first, as discussed in the previous section, is that it looks for valid instruments from within the model, avoiding the risk of selecting - often theoretically weak - external instruments. The second is that current investment decisions have a strong path dependence due to depreciation component and to the fact that it is a structural component of the economy. This means that the lagged dependent variable should be included among the regressors, making (1) a dynamic model:

$$
\begin{gathered}
G F C F_{i x t}=\beta_{1} G F C F_{i x t-1}+\beta_{2} G D P_{-} G_{i t}+\beta_{3} P O L_{-} S T A B_{i t}+\beta_{4} I N F L_{i t}+\beta_{5} E M P L_{i x t}+\beta_{6} V A_{-} G D P_{i x t} \\
+\beta_{7} F D I_{i x t}+\delta_{t}+\varepsilon_{i x t}
\end{gathered}
$$

The dynamic nature of equation (4) suggests taking autocorrelation duly into account to avoid the standard OLS estimator producing biased coefficients. GMM is normally well suited for dynamic models with samples including a short time period and a large cross-section, as in our case. While in the first step the first difference of equation (4) drops out the cross-sectional fixed effects, the second step consists of constructing suitable instruments for the endogenous variables. We treat lagged GFCF and all the FDI-related variables as endogenous, on the ground of a potential reverse causality, and we instrument them using their lagged levels and differences. Additional instruments are represented by the strictly exogenous variables, i.e. all the remaining from equation (4). Since our panel is highly unbalanced, we correct our estimator applying orthogonal deviations as recommended by Arellano and Bover (1995). We also include year fixed effects in order to control for time specific effects as well as to avoid contemporaneous correlation among individuals across time (Roodman, 2009).

Still, despite the cross-sectional dimension is not as small as in previous studies considering the addition of the industry level, we try to keep the number of instruments under control to preserve the stability of the over-identification test. We do this by using the second and third lags of the dependent variable and the 
first to the fourth for the other endogenous variables. Lastly, we make the standard errors of the two-step model robust by adopting the correction suggested by Windmeijer (2005). In order to control for the exclusion of second order correlation and to check for over-identifying restrictions we run the Arellano-Bond and the Hansen tests at the end of each output.

Table 7 reports the results of our main specification using the GMM method. All over the different columns, the Arellano-Bond test supports the null of no second order autocorrelation, while the Hansen test demonstrates that over identification restrictions are valid, and not compromised by the presence of too many instruments.

\section{TABLE 7 HERE}

Results, on the other hand, confirm the findings of existing literature (Farla et al. 2014; Ashraf and Herzer, 2014) showing that even disaggregating the data the industry level, GFCF reports a strong path dependence, being strongly correlated with its previous year's levels. Differently from the IV estimates, we can easily instrument all the FDI-related variables, including the more disaggregated ones. By doing this, we show that there are little changes compared to the results discussed in previous sections. Also in this case, in fact, we do not only find that there is generally a positive effect of FDI on GFCF, but also that this effect is statistically significant only when new investment projects are directed to productive activities.

\section{Conclusions}

In this paper, we have analysed the impact of greenfield FDI on capital accumulation in developing countries with a firm- and industry-level measure of FDI that allows overcoming the limitations of investment flows, the main FDI measure in the extant literature. Our disaggregated data allow a more detailed analysis of FDI spillovers on the host economies, including the differential impact of foreign firms according to their country of origin (whether from the North or from the South), and to the business activity performed by foreign affiliates (production or trade-related). Our results show that detailed analyses on micro data allow assessing the impact of different types of FDI as an effective means for financing development. 
Our main results confirm that FDI exert positive spillovers on total investment, in particular within the recipient industries. More specifically, we contribute to overcome some of the inconclusive results in the literature (Morrissey and Udomkerdmongkol, 2016) in a two major ways.

First, we explore whether different types of FDI have diverse impact on domestic investment; foreign affiliates with productive activities are more beneficial to host economies. Instead, foreign affiliates performing trade-related activities, such as sales, marketing, client support, are less likely to have a positive impact on total investment and they could even contribute to reduce the overall size of the investment in the industry. This suggests that FDI attraction policies by developing economies should better consider linking incentives to the business activities of foreign affiliates. However, this increase in total investment goes along with a crowding out of domestic investment in each recipient industry, i.e. the amount of FDI inflows displaces domestic investment more than proportionally. This displacement effect seems to be dramatically large in the case of trade-related FDI, i.e. FDI that entails no productive activities in the domestic economy.

Second, the impact of FDI on domestic GFCF largely depends on the technological distance between investing and recipient countries; Northern FDI seem to have a net positive impact on GFCF in developing economies, but it does not seem to be the same for Southern FDI. This result might be explained by the relatively low share of Southern investment in the South, compared to Northern investment, to the lower average Southern firms' age, and to the more recent presence of Southern MNEs in other developing economies: all of these factors might imply that negative short run effects as suggested in De Backer and Sleuwaegen (2003) could dominate, whereas the potentially positive long run effects have still to work themselves out. In fact, our evidence suggests that the competition effects of Southern FDI might compensate for the knowledge spillovers accruing to domestic firms, so that the net effect is uncertain, at least in the short run.

Finally, even if and when FDI contribute to increase total investment in host economies, they might still displace domestic investment in recipient industries, generating a trade-off. Further research is needed on which type of FDI is more likely to foster domestic capital accumulation together with total investment. This would contribute to expand our knowledge of how to better design FDI attraction policies to maximise the developmental impact of foreign capital in developing economies. 


\section{References}

Adams, S. (2009). Foreign direct investment, domestic investment, and economic growth in Sub-Saharan Africa. Journal of Policy Modeling, 31(6), 939-949.

Agosin, M., \& Machado, R. (2005). Foreign investment in developing countries: Does it crowd in domestic investment? Oxford Development Studies, 33(2), 149-162.

Agosin, M. R., \& Mayer, R. (2000). Foreign investment in developing countries, does it crowd in domestic investment? UNCTAD discussion papers 146. United Nations Conference on Trade and Development.

Aitken, Brian J. and Harrison, Ann E. June 1999. Do Domestic Firms Benefit from Direct Foreign Investment? American Economic Review 89(3).

Al-Sadig, A. (2013). The effects of foreign direct investment on private domestic investment: Evidence from developing countries. Empirical Economics, 44(4), 12671275.

Amighini, A. and Sanfilippo, M. (2014) Impact of South-South FDI and Trade on the Export Upgrading of African Economies, World Development, 64: 1-17.

Apergis, N., Katrakilidis, C. P., \& Tabakis, N. M. (2006). Dynamic linkages between FDI inflows and domestic investment: A panel cointegration approach, Atlantic Economic Journal, 34(4), 385-394.

Ashraf, A. and D. Herzer (2014) The effects of greenfield investment and M\&As on domestic investment in developing countries, Applied Economics Letters, 21(14): 9971000 .

Blalock, G. and P. J. Gertler (2008), Welfare gains from Foreign Direct Investment through technology transfer to local suppliers, Journal of International Economics, 74(2), 402421.

Blomstrom, Magnus, and Hakan Persson (1989) Foreign Investment and Spillovers. Routledge, London and New York

Borensztein, E., De Gregorio, J., \& Lee, J.-W. (1998). How does foreign direct investment affect economic growth? Journal of International Economics, 45(1), 115-135.

Bosworth, B. P., \& Collins, S. M. (1999). Capital flows to developing economies: Implications for saving and investment. Brookings Papers on Economic Activity, 1999(1), 143-180.

Bougrine, H. \& A. Faroque, "The Relative Impacts of Foreign Direct Investment vs. Long Term Debt Capital on Domestic Investment in Morocco: An Econometric Assessment", Journal of Economic Development, V. 17, Number 1, June 1992

Brecher, R.A. \& Diaz-Alejandro, C.F. (1977), "Tariffs, foreign capital and immiserizing growth", Journal of International Economics, Elsevier, vol. 7(4): 317-322, November.

Calderon, C., N. Loayza \& Serven, L. (2004), Greenfield Foreign Direct Investment and Mergers and Acquisitions: Feedback and Macroeconomic Effects, World Bank Policy Research Working Paper 3192 
Cardoso, E. \& Dornbusch, R. (1988), "Brazilian Debt: A Requiem for Muddling Through", CEPR Discussion Papers 243.

Cuervo-Cazurra, A. and Genc, M. (2008) Transforming disadvantages into advantages: developing-country MNEs in the least developed countries, Journal of International Business Studies, 39, 957-979

de Mello, L. (1999), Foreign Direct Investment-led Growth: Evidence from Time Series and Panel Data. Oxford Economic Papers 51: 133-151.

Farla, K., D. de Combruggher \& B. Vertspagen (2014), Institutions, Foreign Direct Investment, and Domestic Investment: Crowding Out or Crowding In?, World Development.

Fry, Maxwell, "Some Lessons for South Asia from Developing Country Experience with Foreign Direct Investment," Internal Discussion Paper, The World Bank South Asia Region, June 1993

Grieco, J.M. (1986), "Foreign Investment and Development: Theories and Evidence", in T. Moran, ed. Investing in Development: New Roles for Private Capital?, Overseas Development Council, Washington D.C.

Harrison, A. \& McMillan, M. (2003), "Does direct foreign investment affect domestic firm credit constraints?", Journal of International Economics, 61(1), 73-100.

Helleiner, G.K. (1988), "Transnational Corporations and Direct Foreign Investment", in ed. H. Chenery and T.N. Srinivassan, Handbook of Development Economics, Vol. II, Ch. 27

Herzer, D. (2012), "How Does Foreign Direct Investment Really Affect Developing Countries' Growth?", Review of International Economics, Wiley Blackwell, vol. 20(2): 396-414, 05.

Katikati, J.A. (1992) Causality between Direct Foreign Investment and Economic Output in Ghana, Journal of Economic Development, V. 17, Number 1, June 1992

Kim DD, Seo J (2003) Does FDI in flow crowd out domestic investment in Korea? Journal of Economic Studies 30(6): 605-622.

Lall, S. \& Streeten, P. (1977), Foreign Investment, Transnationals and Developing Countries. London: MacMillan.

Lipsey, R. E. (2000). Interpreting developed countries' foreign direct investment. NBER working papers 7810. National Bureau of Economic Research, Inc.

Matos, L. (1977), "Multinational corporations and transfer of technology: the case of Venezuela", in Germidis, D. (ed.), Transfer of Technology by Multinational Corporations, Vol. 1, Development Centre of the Organization for Economic Cooperation and Development, Paris.

Misun, J., \& Tomsik, V. (2002). Does foreign direct investment crowd in or crowd out domestic investment? Eastern European Economics, 40(2), 38. 
Morrissey, O., \& Udomkerdmongkol, M. (2012). Governance, private investment and foreign direct investment in developing countries. World Development, 40(3), 437445.

Morrissey, O., \& Udomkerdmongkol, M. (2016). Response to 'Institutions, Foreign Direct Investment, and Domestic Investment: Crowding Out or Crowding In?' World Development Vol. 88, pp. 10-11.

Munemo, J. (2014) Business start-up regulations and the complementarity between foreign and domestic investment, Review of World Economics, 150: 745-761.

Mutenyo, J., Asmah, E., \& Kalio, A. (2010). Does foreign direct investment crowd-out domestic private investment in Sub-Saharan Africa? The African Finance Journal, 12(1), 27-52.

Ndikumana, L., \& Verick, S. (2008). The linkages between FDI and domestic in-vestment: Unravelling the developmental impact of foreign investment in Sub-Saharan Africa. Development Policy Review, 26(6), 713-726.

OECD (2014) Development Co-operation Report 2014 - Mobilising Resources for Sustainable Development, Paris: OECD

Ramirez, M. (2011). Is foreign direct investment productive in the Latin America case? A panel co-integration analysis, 1980-2002. The International Trade Journal, 25(1), 3573.

Rhee, Y.W. \& T. Belot, "Export Catalysts in Low-Income Countries", Industry and Energy Department, Industry Series Paper No. 5, The World Bank, 1989.

Rodrik, D. (2006), Goodbye Washington Consensus, Hello Washington Confusion?, available at https://www.sss.ias.edu/files/pdfs/Rodrik/Research/GoodbyeWashinhgton.pdf

Sanfilippo, M. and Seric, A. (2015) Spillovers from agglomerations and inward FDI. A Multilevel Analysis on SSA domestic firms, Review of World Economics, forthcoming

Solow, Robert M. (1956), A contribution to the theory of economic growth. Quarterly Journal of Economics, 70, 65-94.

Tang, S., Selvanathan, E. A., \& Selvanathan, S. (2008). Foreign direct investment, domestic investment and economic growth in China: A time series analysis. World Economy, 31(10), 1292-1309.

Titarenko, D. (2005), The influence of foreign direct investment on domestic investment processes in Latvia. MPRA paper 18192. University Library of Munich, Germany.

UNCTAD (2013) World Investment Report - Global Value Chains: Investment and Trade for Development, UNCTAD: Geneva

Xu G, Ruifang W (2007), The effect of foreign direct investment on domestic capital formation, trade and economic growth in a transition economy: evidence from China. Global Economy Journal 7(2):1-21.

Van Loo Frances (1977), The effects of foreign direct investment on investment in Canada, Review of Economics and Statistics 59(4):474-481. 
van Ark, B., and M.P. Timmer (2002), "Capital Formation And Foreign Direct Investment In Korea And Taiwan: Coping With Diminishing Returns", in J.T. Lindblad (ed.), Asian Growth and Foreign Capital: Case Studies from Eastern Asia, Amsterdam: Aksant, pp.59-98.

Wells, L. T. (1993), Developing Country Investors in Indonesia, Bulletin of Indonesian Economic Studies 15(1):69-84.

World Bank (2001), Global Development Finance 2001, Washington, D. C. 


\section{Tables and Figures}

Table 1. FDI by manufacturing industry in the 53 developing countries in sample

\begin{tabular}{cccccccccc} 
& $\begin{array}{c}\text { Food\& } \\
\text { beverages } \\
\text { (15) }\end{array}$ & $\begin{array}{c}\text { Textiles } \\
\mathbf{( 1 7 )}\end{array}$ & $\begin{array}{c}\text { Chemicals } \\
\mathbf{( 2 4 )}\end{array}$ & $\begin{array}{c}\text { Rubber } \\
\text { \&plastics } \\
\mathbf{( 2 5 )}\end{array}$ & $\begin{array}{c}\text { Basic } \\
\text { Metals } \\
\mathbf{( 2 7 )}\end{array}$ & $\begin{array}{c}\text { Machinery } \\
\text { \&equip. } \\
\mathbf{( 2 9 )}\end{array}$ & $\begin{array}{c}\text { Electrical } \\
\text { mach } \\
\mathbf{( 3 1 )}\end{array}$ & $\begin{array}{c}\text { Radio, } \\
\text { TV } \\
\mathbf{( 3 2 )}\end{array}$ & $\begin{array}{c}\text { Motor } \\
\text { vehicles } \\
\mathbf{( 3 4 )}\end{array}$ \\
\hline 2003 & 150 & 94 & 102 & 102 & 46 & 71 & 179 & 130 & 203 \\
2004 & 149 & 117 & 122 & 122 & 58 & 102 & 184 & 134 & 180 \\
2005 & 190 & 101 & 124 & 124 & 76 & 122 & 196 & 164 & 198 \\
2006 & 237 & 171 & 148 & 148 & 121 & 151 & 278 & 185 & 265 \\
2007 & 171 & 159 & 224 & 224 & 127 & 252 & 205 & 212 & 302 \\
2008 & 241 & 188 & 239 & 239 & 184 & 297 & 207 & 182 & 366 \\
2009 & 283 & 172 & 264 & 264 & 110 & 261 & 221 & 109 & 290 \\
2010 & 227 & 239 & 260 & 260 & 137 & 258 & 246 & 159 & 275 \\
2011 & 162 & 222 & 181 & 181 & 81 & 157 & 164 & 108 & 173 \\
\hline
\end{tabular}

Source: Authors' elaboration on FDIMarkets

Table 2. Summary statistics

\begin{tabular}{lccccc}
\hline \multicolumn{1}{c}{ Variable } & Obs & Mean & Std. Dev. & Min & Max \\
\hline gfcf_gdp & 4410 & 0.060 & 0.334 & -1.808 & 8.456 \\
gdp_grow & 4410 & 5.227 & 5.024 & -17.955 & 34.500 \\
pol_stab & 4410 & -0.069 & 0.871 & -2.390 & 1.384 \\
infl & 4130 & 5.335 & 4.981 & -2.5 & 44.391 \\
lempl & 4059 & 8.775 & 2.236 & 1.792 & 15.960 \\
va_gdp & 4077 & 0.377 & 2.245 & 0 & 41.865 \\
n_fdi & 4410 & 3.658 & 10.847 & 0 & 134 \\
n_fdi_production & 4410 & 1.294 & 5.062 & 0 & 87 \\
n_fdi_trade & 4410 & 0.707 & 3.237 & 0 & 62 \\
n_fdi_north & 4410 & 3.159 & 9.620 & 0 & 117 \\
n_fdi_south & 4410 & 0.498 & 1.677 & 0 & 33 \\
stock & 4410 & 17.002 & 67.298 & 0 & 970 \\
total_inv_gdp & 4410 & 0.001 & 0.007 & 0 & 0.194 \\
\hline
\end{tabular}


Table 3. Main Results

\begin{tabular}{|c|c|c|c|c|c|c|c|c|}
\hline $\begin{array}{l}\text { Dep. Var: } \\
\text { GFCF on GDP }\end{array}$ & $\begin{array}{l}\text { (1) } \\
\text { n_fdi }\end{array}$ & $\begin{array}{l}\text { (2) } \\
\text { n_fdi }\end{array}$ & $\begin{array}{l}(3) \\
\text { n_fdi }_{-}\end{array}$ & $\begin{array}{l}(4) \\
\text { n_fdi }\end{array}$ & $\begin{array}{l}\text { (5) } \\
\text { stock }\end{array}$ & $\begin{array}{l}\text { (6) } \\
\text { stock }\end{array}$ & $\begin{array}{l}\text { (7) } \\
\text { stock }\end{array}$ & $\begin{array}{l}(8) \\
\text { stock }\end{array}$ \\
\hline n_fdi & $\begin{array}{l}0.0017^{* * *} \\
{[0.000]}\end{array}$ & & & & & & & \\
\hline n_fdi_production & & $\begin{array}{l}0.0036^{* * *} \\
{[0.001]}\end{array}$ & & & & & & \\
\hline n_fdi_trade & & $\begin{array}{l}0.0004 \\
{[0.001]}\end{array}$ & & & & & & \\
\hline n_fdi_north & & & $\begin{array}{l}0.0020^{* * *} \\
{[0.000]}\end{array}$ & & & & & \\
\hline n_fdi_south & & & & $\begin{array}{l}-0.0001 \\
{[0.002]}\end{array}$ & & & & \\
\hline stock & & & & & $\begin{array}{l}0.0002^{* * *} \\
{[0.000]}\end{array}$ & & & \\
\hline stock_production & & & & & & $\begin{array}{l}0.0009^{* * *} \\
{[0.000]}\end{array}$ & & \\
\hline stock_trade & & & & & & $\begin{array}{l}-0.0001 \\
{[0.000]}\end{array}$ & & \\
\hline stock_north & & & & & & & $\begin{array}{l}0.0003^{* * *} \\
{[0.000]}\end{array}$ & \\
\hline stock_south & & & & & & & & $\begin{array}{l}0.0003 \\
{[0.000]}\end{array}$ \\
\hline Constant & $\begin{array}{l}0.3489^{* * *} \\
{[0.048]}\end{array}$ & $\begin{array}{l}0.3523^{* * *} \\
{[0.048]}\end{array}$ & $\begin{array}{l}0.3490^{* * *} \\
{[0.048]}\end{array}$ & $\begin{array}{l}0.3539^{* * *} \\
{[0.048]}\end{array}$ & $\begin{array}{l}0.3527^{* * *} \\
{[0.048]}\end{array}$ & $\begin{array}{l}0.3559^{* * *} \\
{[0.048]}\end{array}$ & $\begin{array}{l}0.3528^{* * *} \\
{[0.048]}\end{array}$ & $\begin{array}{l}0.3534^{* * *} \\
{[0.048]}\end{array}$ \\
\hline Observations & 4,410 & 4,410 & 4,410 & 4,410 & 4,410 & 4,410 & 4,410 & 4,410 \\
\hline R-squared & 0.269 & 0.270 & 0.270 & 0.268 & 0.269 & 0.271 & 0.269 & 0.268 \\
\hline
\end{tabular}

Robust standard errors in brackets

${ }^{* * *} \mathrm{p}<0.01,{ }^{* *} \mathrm{p}<0.05,{ }^{*} \mathrm{p}<0.1$

Note: All the specifications include country-, industry- and year-effects 
Table 4. Main Results, including controls

\begin{tabular}{|c|c|c|c|c|c|c|c|c|}
\hline $\begin{array}{l}\text { Dep. Var: } \\
\text { GFCF on GDP }\end{array}$ & $\begin{array}{l}\text { (1) } \\
\text { n_fdi }\end{array}$ & $\begin{array}{l}\text { (2) } \\
\text { n_fdi }\end{array}$ & $\begin{array}{l}\text { (3) } \\
\text { n_fdi }\end{array}$ & $\begin{array}{l}\text { (4) } \\
\text { n_fdi }\end{array}$ & $\begin{array}{l}\text { (5) } \\
\text { stock }\end{array}$ & $\begin{array}{l}\text { (6) } \\
\text { stock }\end{array}$ & $\begin{array}{l}\text { (7) } \\
\text { stock }\end{array}$ & $\begin{array}{l}\text { (8) } \\
\text { stock }\end{array}$ \\
\hline gdp_grow & $\begin{array}{l}-0.0003 \\
{[0.000]}\end{array}$ & $\begin{array}{l}-0.0003 \\
{[0.000]}\end{array}$ & $\begin{array}{c}-0.0003 \\
{[0.000]}\end{array}$ & $\begin{array}{l}-0.0003 \\
{[0.000]}\end{array}$ & $\begin{array}{c}-0.0003 \\
{[0.000]}\end{array}$ & $\begin{array}{l}-0.0003 \\
{[0.000]}\end{array}$ & $\begin{array}{c}-0.0003 \\
{[0.000]}\end{array}$ & $\begin{array}{l}-0.0003 \\
{[0.000]}\end{array}$ \\
\hline pol_stab & $\begin{array}{l}0.0057 \\
{[0.017]}\end{array}$ & $\begin{array}{l}0.0074 \\
{[0.017]}\end{array}$ & $\begin{array}{l}0.0057 \\
{[0.017]}\end{array}$ & $\begin{array}{l}0.0060 \\
{[0.017]}\end{array}$ & $\begin{array}{l}0.0054 \\
{[0.017]}\end{array}$ & $\begin{array}{l}0.0056 \\
{[0.017]}\end{array}$ & $\begin{array}{l}0.0053 \\
{[0.017]}\end{array}$ & $\begin{array}{l}0.0060 \\
{[0.017]}\end{array}$ \\
\hline infl & $\begin{array}{l}-0.0002 \\
{[0.001]}\end{array}$ & $\begin{array}{l}-0.0001 \\
{[0.001]}\end{array}$ & $\begin{array}{l}-0.0002 \\
{[0.001]}\end{array}$ & $\begin{array}{l}-0.0002 \\
{[0.001]}\end{array}$ & $\begin{array}{l}-0.0002 \\
{[0.001]}\end{array}$ & $\begin{array}{l}-0.0001 \\
{[0.001]}\end{array}$ & $\begin{array}{l}-0.0002 \\
{[0.001]}\end{array}$ & $\begin{array}{l}-0.0001 \\
{[0.001]}\end{array}$ \\
\hline lempl & $\begin{array}{l}0.0159^{* * *} \\
{[0.004]}\end{array}$ & $\begin{array}{l}0.0157^{* * *} \\
{[0.004]}\end{array}$ & $\begin{array}{l}0.0159^{* * *} \\
{[0.004]}\end{array}$ & $\begin{array}{l}0.0169^{* * *} \\
{[0.004]}\end{array}$ & $\begin{array}{l}0.0163^{* * *} \\
{[0.004]}\end{array}$ & $\begin{array}{l}0.0155^{* * *} \\
{[0.004]}\end{array}$ & $\begin{array}{l}0.0162^{* * *} \\
{[0.004]}\end{array}$ & $\begin{array}{l}0.0170^{* * *} \\
{[0.004]}\end{array}$ \\
\hline va_gdp & $\begin{array}{l}0.0942^{* * *} \\
{[0.034]}\end{array}$ & $\begin{array}{l}0.0941^{* * *} \\
{[0.034]}\end{array}$ & $\begin{array}{l}0.0942^{* * *} \\
{[0.034]}\end{array}$ & $\begin{array}{l}0.0942^{* * *} \\
{[0.034]}\end{array}$ & $\begin{array}{l}0.0942^{* * *} \\
{[0.034]}\end{array}$ & $\begin{array}{l}0.0940^{* * *} \\
{[0.034]}\end{array}$ & $\begin{array}{l}0.0942^{* * *} \\
{[0.034]}\end{array}$ & $\begin{array}{l}0.0942^{* * *} \\
{[0.034]}\end{array}$ \\
\hline $\mathrm{n}_{-} \mathrm{fdi}$ & $\begin{array}{l}0.0011^{* *} \\
{[0.000]}\end{array}$ & & & & & & & \\
\hline n_fdi_production & & $\begin{array}{l}0.0031^{* * *} \\
{[0.001]}\end{array}$ & & & & & & \\
\hline n_fdi_trade & & $\begin{array}{l}0.0002 \\
{[0.001]}\end{array}$ & & & & & & \\
\hline n_fdi_north & & & $\begin{array}{l}0.0013^{* *} \\
{[0.001]}\end{array}$ & & & & & \\
\hline n_fdi_south & & & & $\begin{array}{l}-0.0004 \\
{[0.003]}\end{array}$ & & & & \\
\hline stock & & & & & $\begin{array}{l}0.0001 \\
{[0.000]}\end{array}$ & & & \\
\hline stock_production & & & & & & $\begin{array}{l}0.0010^{* * *} \\
{[0.000]}\end{array}$ & & \\
\hline stock_trade & & & & & & $\begin{array}{l}-0.0001 \\
{[0.000]}\end{array}$ & & \\
\hline stock_north & & & & & & & $\begin{array}{l}0.0002^{*} \\
{[0.000]}\end{array}$ & \\
\hline stock_south & & & & & & & & $\begin{array}{l}-0.0004 \\
{[0.001]}\end{array}$ \\
\hline Constant & $\begin{array}{l}0.0574 \\
{[0.037]}\end{array}$ & $\begin{array}{l}0.0616^{*} \\
{[0.037]}\end{array}$ & $\begin{array}{l}0.0584 \\
{[0.037]}\end{array}$ & $\begin{array}{l}0.0510 \\
{[0.037]}\end{array}$ & $\begin{array}{l}0.0562 \\
{[0.037]}\end{array}$ & $\begin{array}{l}0.0665^{*} \\
{[0.036]}\end{array}$ & $\begin{array}{l}0.0571 \\
{[0.037]}\end{array}$ & $\begin{array}{l}0.0503 \\
{[0.037]}\end{array}$ \\
\hline Observations & 3,628 & 3,628 & 3,628 & 3,628 & 3,628 & 3,628 & 3,628 & 3,628 \\
\hline R-squared & 0.444 & 0.444 & 0.444 & 0.443 & 0.443 & 0.445 & 0.444 & 0.443 \\
\hline
\end{tabular}

Robust standard errors in brackets

${ }^{* * *} \mathrm{p}<0.01,{ }^{* *} \mathrm{p}<0.05,{ }^{*} \mathrm{p}<0.1$

Note: All the specifications include country-, industry- and year-effects 
Table 5. Results, using FDI flows rather than N

\begin{tabular}{|c|c|c|c|c|}
\hline $\begin{array}{l}\text { Dep. Var.: } \\
\text { GFCF on GDP }\end{array}$ & (1) & (2) & (3) & (4) \\
\hline gdp_grow & $\begin{array}{l}-0.0003 \\
{[0.000]}\end{array}$ & $\begin{array}{l}-0.0003 \\
{[0.000]}\end{array}$ & $\begin{array}{l}-0.0003 \\
{[0.000]}\end{array}$ & $\begin{array}{l}-0.0003 \\
{[0.000]}\end{array}$ \\
\hline pol_stab & $\begin{array}{l}0.0061 \\
{[0.017]}\end{array}$ & $\begin{array}{l}0.0066 \\
{[0.017]}\end{array}$ & $\begin{array}{l}0.0057 \\
{[0.017]}\end{array}$ & $\begin{array}{l}0.0060 \\
{[0.017]}\end{array}$ \\
\hline lempl & $\begin{array}{l}0.0165^{* * * *} \\
{[0.004]}\end{array}$ & $\begin{array}{l}0.0166^{* * * *} \\
{[0.004]}\end{array}$ & $\begin{array}{l}0.0165^{* * * *} \\
{[0.004]}\end{array}$ & $\begin{array}{l}0.0168^{* * *} \\
{[0.004]}\end{array}$ \\
\hline infl & $\begin{array}{l}-0.0002 \\
{[0.001]}\end{array}$ & $\begin{array}{l}-0.0002 \\
{[0.001]}\end{array}$ & $\begin{array}{l}-0.0002 \\
{[0.001]}\end{array}$ & $\begin{array}{l}-0.0002 \\
{[0.001]}\end{array}$ \\
\hline va_gdp & $\begin{array}{l}0.0942^{* * *} \\
{[0.034]}\end{array}$ & $\begin{array}{l}0.0941^{* * * *} \\
{[0.034]}\end{array}$ & $\begin{array}{l}0.0942^{* * *} \\
{[0.034]}\end{array}$ & $\begin{array}{l}0.0942^{* * *} \\
{[0.034]}\end{array}$ \\
\hline total_inv_gdp & $\begin{array}{l}0.5905^{* *} \\
{[0.233]}\end{array}$ & & & \\
\hline total_inv_prod_gdp & & $\begin{array}{l}0.6001^{* *} \\
{[0.244]}\end{array}$ & & \\
\hline total_inv_trade_gdp & & $\begin{array}{l}-5.1715^{* *} \\
{[2.280]}\end{array}$ & & \\
\hline total_inv_north_gdp & & & $\begin{array}{l}0.7528^{* *} \\
{[0.357]}\end{array}$ & \\
\hline total_inv_south_gdp & & & & $\begin{array}{l}0.1856 \\
{[0.370]}\end{array}$ \\
\hline Constant & $\begin{array}{l}0.0524 \\
{[0.037]}\end{array}$ & $\begin{array}{l}0.0581 \\
{[0.037]}\end{array}$ & $\begin{array}{l}0.0523 \\
{[0.037]}\end{array}$ & $\begin{array}{l}0.0510 \\
{[0.037]}\end{array}$ \\
\hline Observations & 3,628 & 3,628 & 3,628 & 3,628 \\
\hline R-squared & 0.443 & 0.444 & 0.443 & 0.443 \\
\hline
\end{tabular}

Robust standard errors in brackets

${ }^{* * *} \mathrm{p}<0.01,{ }^{* *} \mathrm{p}<0.05,{ }^{*} \mathrm{p}<0.1$

Note: All the specifications include country-, industry- and year-effects 
Table 6. Results, IV 2SLS model (first and second stage)

\begin{tabular}{|c|c|c|c|c|}
\hline $\begin{array}{l}\text { First stage } \\
\text { Dep. Var.: N_FDI }\end{array}$ & (1) & $(2)$ & (3) & (4) \\
\hline sector_share_fdi & $\begin{array}{c}49.44435^{* * *} \\
(.046915)\end{array}$ & $\begin{array}{l}48.87105^{* * *} \\
(9.834426)\end{array}$ & $\begin{array}{l}48.85946^{* * *} \\
(9.829297)\end{array}$ & $\begin{array}{c}48.83301^{* * *} \\
(9.83011)\end{array}$ \\
\hline lfdi_total & $\begin{array}{c}.839255^{*} \\
(.4349751)\end{array}$ & & & \\
\hline gdp_g_weight & $\begin{array}{l}.0559042 \\
(.046915)\end{array}$ & $\begin{array}{c}.0178074 \\
(.0409737)\end{array}$ & & \\
\hline xr_rate_weight & $\begin{array}{l}.0400197^{* *} \\
(.0185126)\end{array}$ & & $\begin{array}{l}.0341904^{*} \\
(.0341904)\end{array}$ & \\
\hline $\begin{array}{l}\text { Second stage } \\
\text { Dep. Var.: GFCF on GDP }\end{array}$ & (1) & (2) & (3) & (4) \\
\hline n_fdi & $\begin{array}{l}0.0093 \\
{[0.008]}\end{array}$ & $\begin{array}{l}0.0127^{*} \\
{[0.007]}\end{array}$ & $\begin{array}{l}0.0076 \\
{[0.009]}\end{array}$ & $\begin{array}{l}0.0128^{*} \\
{[0.007]}\end{array}$ \\
\hline $\begin{array}{l}\text { Observations } \\
\text { Hansen J (p-value) }\end{array}$ & $\begin{array}{c}3,290 \\
0.3211\end{array}$ & $\begin{array}{c}3,374 \\
0.3767\end{array}$ & $\begin{array}{c}3,374 \\
0.3681\end{array}$ & 3,374 \\
\hline
\end{tabular}

Robust standard errors in brackets

*** $\mathrm{p}<0.01,{ }^{* *} \mathrm{p}<0.05,{ }^{*} \mathrm{p}<0.1$

Note: All the specifications include the main control variables, gdp_grow, pol_stab, infl, empl, va_gdp, as well as country-, industry- and year- fixed effects. The dependent variable in the first stage is the number of FDI project received. The combination using sector_share and lfdi_total cannot be computed due to collinearity . 
Table 7. Results, dynamic panel estimator

\begin{tabular}{|c|c|c|c|c|}
\hline $\begin{array}{l}\text { Dep. Var.: } \\
\text { GFCF on GDP }\end{array}$ & (1) & (2) & (3) & (4) \\
\hline L.gfcf_gdp & $\begin{array}{l}0.7012^{* * *} \\
{[0.107]}\end{array}$ & $\begin{array}{l}0.6948^{* * *} \\
{[0.103]}\end{array}$ & $\begin{array}{l}0.7133^{* * *} \\
{[0.118]}\end{array}$ & $\begin{array}{l}0.6945^{* * *} \\
{[0.098]}\end{array}$ \\
\hline gdp_grow & $\begin{array}{l}0.0001 \\
{[0.000]}\end{array}$ & $\begin{array}{l}0.0001 \\
{[0.000]}\end{array}$ & $\begin{array}{l}0.0001 \\
{[0.000]}\end{array}$ & $\begin{array}{l}0.0001 \\
{[0.000]}\end{array}$ \\
\hline pol_stab & $\begin{array}{l}0.0036^{*} \\
{[0.002]}\end{array}$ & $\begin{array}{l}0.0041^{*} \\
{[0.002]}\end{array}$ & $\begin{array}{l}0.0034^{*} \\
{[0.002]}\end{array}$ & $\begin{array}{l}0.0035 \\
{[0.002]}\end{array}$ \\
\hline lempl & $\begin{array}{l}-0.0006 \\
{[0.001]}\end{array}$ & $\begin{array}{l}-0.0004 \\
{[0.001]}\end{array}$ & $\begin{array}{l}-0.0005 \\
{[0.001]}\end{array}$ & $\begin{array}{l}-0.0003 \\
{[0.001]}\end{array}$ \\
\hline infl & $\begin{array}{l}0.0001 \\
{[0.000]}\end{array}$ & $\begin{array}{l}0.0001 \\
{[0.000]}\end{array}$ & $\begin{array}{l}0.0000 \\
{[0.000]}\end{array}$ & $\begin{array}{l}0.0001 \\
{[0.000]}\end{array}$ \\
\hline va_gdp & $\begin{array}{l}0.0646^{*} \\
{[0.036]}\end{array}$ & $\begin{array}{l}0.0663^{*} \\
{[0.035]}\end{array}$ & $\begin{array}{l}0.0607 \\
{[0.040]}\end{array}$ & $\begin{array}{l}0.0670^{* *} \\
{[0.033]}\end{array}$ \\
\hline n_fdi & $\begin{array}{l}0.0004^{*} \\
{[0.000]}\end{array}$ & & & \\
\hline n_fdi_production & & $\begin{array}{l}0.0006 \\
{[0.001]}\end{array}$ & & \\
\hline n_fdi_trade & & $\begin{array}{l}0.0000 \\
{[0.000]}\end{array}$ & & \\
\hline n_fdi_north & & & $\begin{array}{l}0.0005^{* *} \\
{[0.000]}\end{array}$ & \\
\hline n_fdi_south & & & & $\begin{array}{l}0.0003 \\
{[0.003]}\end{array}$ \\
\hline Constant & $\begin{array}{l}0.0027 \\
{[0.004]}\end{array}$ & $\begin{array}{l}0.0023 \\
{[0.007]}\end{array}$ & $\begin{array}{l}0.0020 \\
{[0.004]}\end{array}$ & $\begin{array}{l}0.0013 \\
{[0.005]}\end{array}$ \\
\hline Observations & 2,858 & 2,858 & 2,858 & 2,858 \\
\hline Number of panel & 550 & 550 & 550 & 550 \\
\hline Hansen (p-value) & 0.661 & 0.805 & 0.556 & 0.308 \\
\hline ar2 (p-value) & 0.822 & 0.813 & 0.838 & 0.813 \\
\hline N. of instruments & 66 & 99 & 66 & 66 \\
\hline
\end{tabular}

Robust standard errors in brackets

${ }^{* * *} \mathrm{p}<0.01,{ }^{* *} \mathrm{p}<0.05,{ }^{*} \mathrm{p}<0.1$ 
Figure 1. Initial investment size and number of linkages with domestic suppliers* (left) and (log) investment in fixed assets (right)

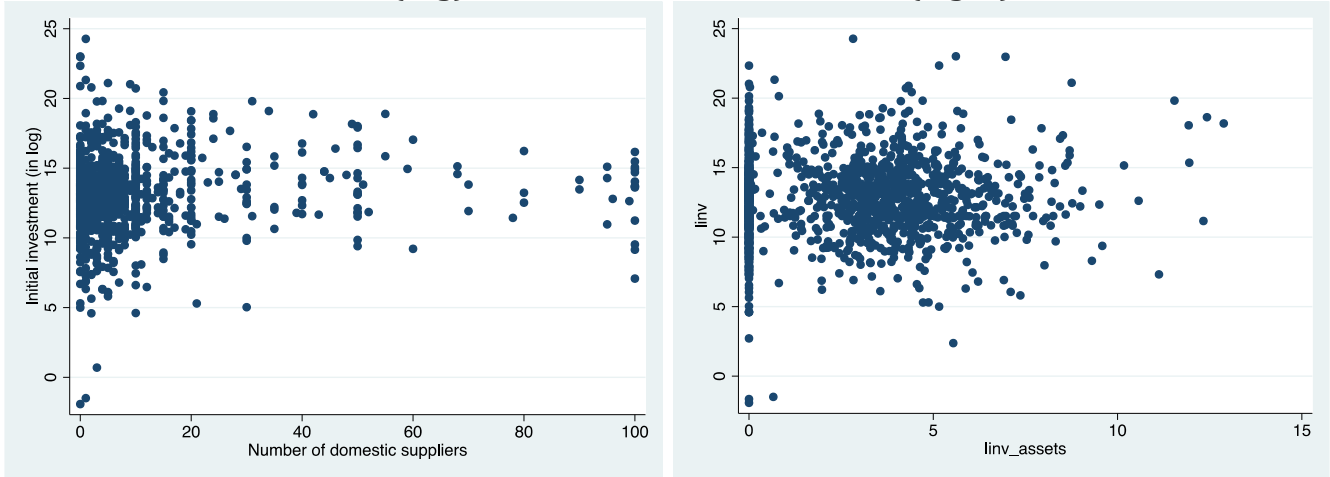

Source: Authors' elaboration on African Investor Survey data (UNIDO, 2012)

*A threshold of 100 domestic suppliers, corresponding to the $95^{\text {th }}$ percentile of the distribution, has been selected to avoid outliers.

Figure 2. N. of FDI by main business activity

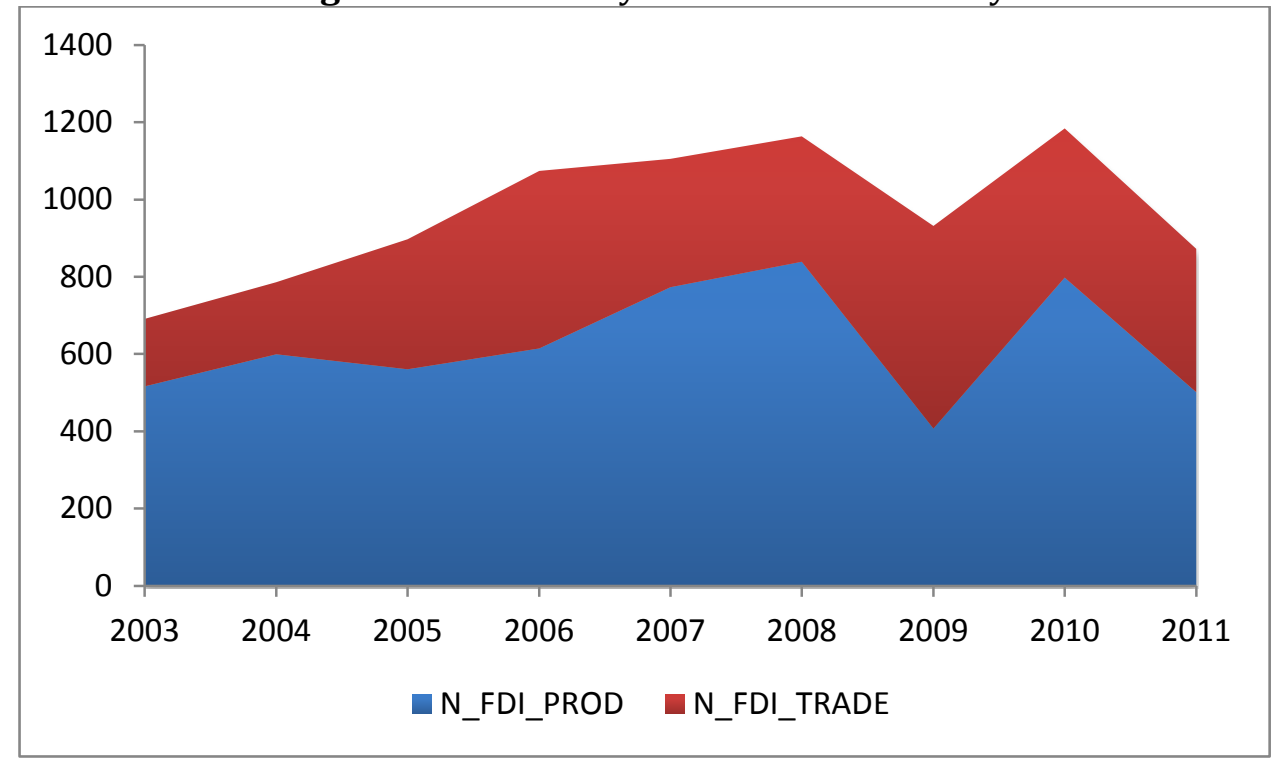

Source: Authors' elaboration on FDIMarkets

Note: N_FDI_PROD includes foreign firms doing manufacturing production in host economies, while N_FDI_TRADE includes foreign firms that enter the host economy in one of the 2-digit industries included in the analysis to perform other business activities that do not include production, such as sales, marketing, support and retail/wholesale. 
Figure 3. FDI flows (billion \$, left axe) and numbers (right axe)

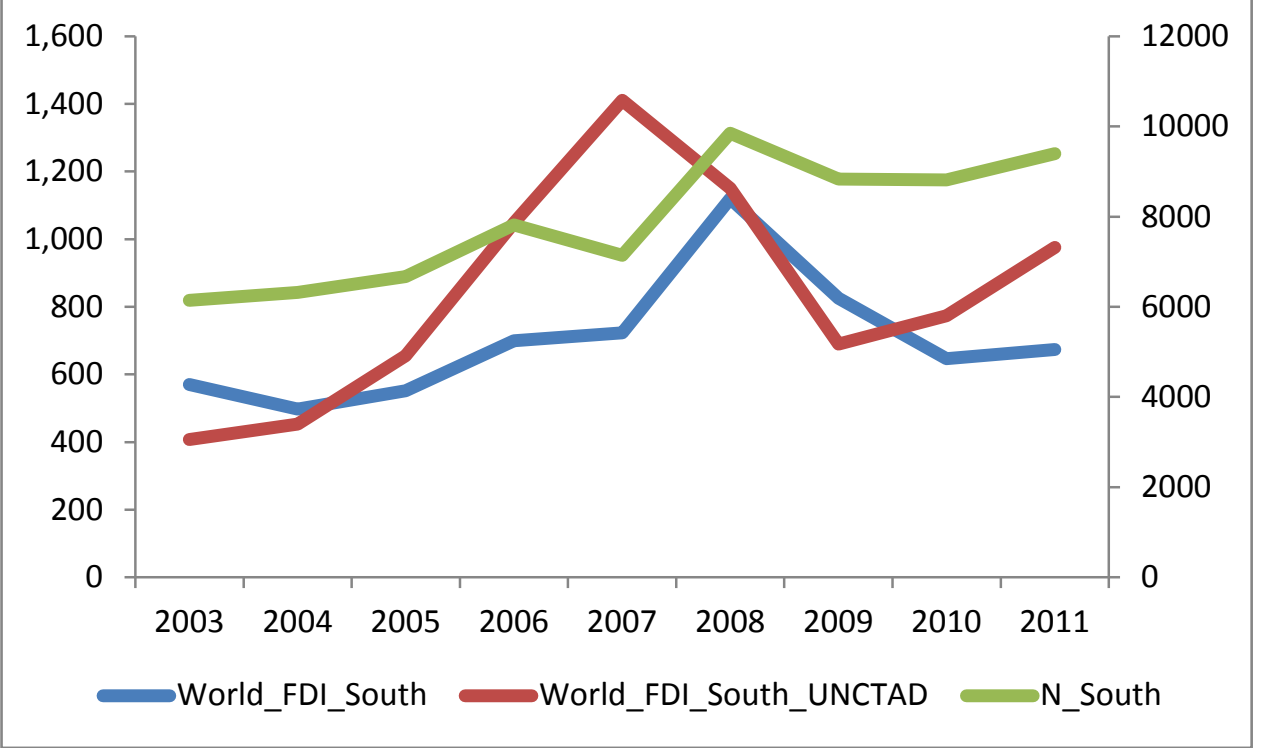

Source: Authors' elaboration on FDIMarkets and UNCTAD FDI Statistics 
APPENDIX A

Table A1: Inward FDI and Domestic Capital Formation: Empirical Evidence

\begin{tabular}{|c|c|c|c|c|}
\hline Date & Author(s) & Methodology & Countries & Results \\
\hline 2014 & Munemo & OLS and GMM & 139 countries & $\begin{array}{l}+(\text { conditional on good } \\
\text { business regulation })\end{array}$ \\
\hline 2014 & Ashaf and Herzer & FE and GMM & 100 countries & - (greenfield only) \\
\hline 2014 & Farla et al & GMM & 46 countries & + \\
\hline 2013 & Al-Sadig & GMM & 91 countries & + \\
\hline 2012 & $\begin{array}{l}\text { Morrissey \& } \\
\text { Udomkerdmongkol }\end{array}$ & GMM & 46 countries & - \\
\hline 2011 & Ramirez & & Latin America & + \\
\hline 2010 & Mutenyo et al & & & \\
\hline 2009 & Adams & OLS, FE & SSA & - \\
\hline 2008 & Ndikumana \& Verick & FE & SSA & + \\
\hline 2008 & Tang et al & ECM & China & + \\
\hline 2006 & Apergis et al & & 30 countries & +/- (depending on regions) \\
\hline 2005 & Agosin \& Machado & GMM & 36 countries & - \\
\hline 2005 & Titarenko & LS & Latvia & - \\
\hline 2002 & Misun \& Tomsik & & CZ, HU, PO & $+/-$ \\
\hline 2000 & Agosin \& Mayer & & $\begin{array}{l}\text { developing } \\
\text { countries }\end{array}$ & $+/-$ \\
\hline 2000 & Lipsey & & $\begin{array}{l}\text { OECD } \\
\text { countries }\end{array}$ & none \\
\hline 1999 & Bosworth \& Collins & IV & 58 countries & + \\
\hline 1999 & de Mello & TS & 33 countries & + \\
\hline 1998 & Borensztein et al & & $\begin{array}{l}69 \text { developing } \\
\text { countries }\end{array}$ & + \\
\hline 1997 & Mbekeani & 2SLS ECM & South Africa & + \\
\hline 1997 & Aitken \& Harrison & TS, panel, FE & Venezuela & + for JV, - no local partner \\
\hline 1997 & Fry & TS, SM, 3SLS & 46 countries & + \\
\hline 1993 & Wells & case studies & East Asia & + \\
\hline 1993 & Wells \& Warren & case studies & Indonesia & + \\
\hline 1993 & Fry & TS, SM, 3SLS & 16 countries & $\begin{array}{l}+/- \text { depending on policies in } \\
\text { place }(2)\end{array}$ \\
\hline 1992 & Katikati & TS, Granger & Ghana & - \\
\hline 1992 & Faroque \& Bougrine & SM, TS & Morocco & - \\
\hline 1989 & Rhee \& Belot & case studies & 11 countries & - \\
\hline 1986 & Encarnation \& Wells & case studies & Asia & $\begin{array}{l}+/- \text { depending on policies in } \\
\text { place }(2)\end{array}$ \\
\hline 1977 & Matos & case study & Venezuela & - \\
\hline
\end{tabular}

Notes: (1) Prior to 1975, several studies were done on the impact of MNCs in Latin America. Most of these are case studies and it would be impossible to list all of them in this table. For a good summary of these see Grieco (1986). (2) For example, Encarnation \& Wells find that where FDI substitutes for imports because it is "tariffjumping", the overall impact on the host country is negative. 
Table A2 - Developing countries included in sample

\begin{tabular}{|c|c|c|}
\hline Country & Obs & $\%$ on total \\
\hline Azerbaijan & 140 & 3.28 \\
\hline Eritrea & 138 & 3.24 \\
\hline Lithuania & 138 & 3.24 \\
\hline Singapore & 138 & 3.24 \\
\hline Croatia & 136 & 3.19 \\
\hline Jordan & 135 & 3.17 \\
\hline Latvia & 132 & 3.1 \\
\hline Georgia & 130 & 3.05 \\
\hline Slovakia & 130 & 3.05 \\
\hline Slovenia & 129 & 3.03 \\
\hline Macedonia & 128 & 3 \\
\hline Morocco & 128 & 3 \\
\hline Cyprus & 125 & 2.93 \\
\hline Poland & 122 & 2.86 \\
\hline India & 121 & 2.84 \\
\hline Malaysia & 120 & 2.81 \\
\hline Mexico & 118 & 2.77 \\
\hline Oman & 117 & 2.74 \\
\hline Ethiopia & 110 & 2.58 \\
\hline Turkey & 109 & 2.56 \\
\hline Kuwait & 91 & 2.13 \\
\hline Fiji & 90 & 2.11 \\
\hline Israel & 90 & 2.11 \\
\hline Ecuador & 86 & 2.02 \\
\hline Hungary & 84 & 1.97 \\
\hline Uruguay & 82 & 1.92 \\
\hline China & 79 & 1.85 \\
\hline Albania & 78 & 1.83 \\
\hline Czech republic & 78 & 1.83 \\
\hline Bulgaria & 76 & 1.78 \\
\hline Hong kong & 76 & 1.78 \\
\hline Malawi & 76 & 1.78 \\
\hline Sri lanka & 76 & 1.78 \\
\hline Estonia & 63 & 1.48 \\
\hline Philippines & 59 & 1.38 \\
\hline Moldova & 55 & 1.29 \\
\hline Bermuda & 48 & 1.13 \\
\hline Chile & 42 & 0.99 \\
\hline Macau & 40 & 0.94 \\
\hline Romania & 37 & 0.87 \\
\hline Trinidad and tobago & 37 & 0.87 \\
\hline Tanzana & 34 & 0.8 \\
\hline Egypt & 32 & 0.75 \\
\hline Nepal & 26 & 0.61 \\
\hline
\end{tabular}




\begin{tabular}{lrr} 
Tunisia & 24 & 0.56 \\
Yemen & 21 & 0.49 \\
Bangladesh & 16 & 0.38 \\
Lebanon & 16 & 0.38 \\
Saudi Arabia & 16 & 0.38 \\
Pakistan & 15 & 0.35 \\
Ghana & 13 & 0.3 \\
Colombia & 12 & 0.28 \\
Gambia & 7 & 0.16 \\
\hline Total & 4,219 & 100 \\
\hline
\end{tabular}

Table A3. Variables description

\begin{tabular}{|c|c|}
\hline VARIABLES & DESCRIPTION \& SOURCE \\
\hline $\begin{array}{l}\text { Dependent var } \\
\text { gfc_gdp }\end{array}$ & Gross Fixed Capital Formation on GDP (UNIDO \& WDI) \\
\hline \multicolumn{2}{|l|}{ Main Controls } \\
\hline gdp_growth & GDP growth (WDI) \\
\hline pol_stab & Political Stability (WGI) \\
\hline infl & Inflation, \% change of consumer price index (WDI) \\
\hline lempl & $\begin{array}{l}\text { Number of employees in host country, industry and year, in Log } \\
\text { (UNIDO) }\end{array}$ \\
\hline va_gdp & Value added on GDP in host country, industry and year (UNIDO) \\
\hline \multicolumn{2}{|l|}{ Variables of interest } \\
\hline $\mathrm{n}_{-} \mathrm{fdi}$ & Number of greenfield FDI in host country, industry and year \\
\hline n_fdi_production & $\begin{array}{l}\text { Number of greenfield FDI in Productive activities in host country, } \\
\text { industry and year }\end{array}$ \\
\hline n_fdi_trade & $\begin{array}{l}\text { Number of greenfield FDI in trade-related activities in host } \\
\text { country, industry and year }\end{array}$ \\
\hline n_fdi_north & $\begin{array}{l}\text { Number of greenfield FDI from high-income OECD countries in } \\
\text { host country, industry and year }\end{array}$ \\
\hline n_fdi_south & $\begin{array}{l}\text { Number of greenfield FDI from non high-income OECD countries } \\
\text { in host country, industry and year }\end{array}$ \\
\hline stock & Stock number of greenfield FDI in host country, industry and year \\
\hline stock_production & $\begin{array}{l}\text { Stock number of greenfield FDI in Productive activities in host } \\
\text { country, industry and year }\end{array}$ \\
\hline stock_trade & $\begin{array}{l}\text { Stock number of greenfield FDI in trade-related activities in host } \\
\text { country, industry and year }\end{array}$ \\
\hline stock_north & $\begin{array}{l}\text { Stock number of greenfield FDI from high-income OECD countries } \\
\text { in host country, industry and year }\end{array}$ \\
\hline stock_south & $\begin{array}{l}\text { Stock number of greenfield FDI from non high-income OECD } \\
\text { countries in host country, industry and year }\end{array}$ \\
\hline total_inv_gdp & Total investment flows to host country, industry and year \\
\hline total_inv_gdp_production & $\begin{array}{l}\text { Total investment flows in production activities to host country, } \\
\text { industry and year }\end{array}$ \\
\hline total_inv_gdp_trade & $\begin{array}{l}\text { Total investment flows in trade activities to host country, industry } \\
\text { and year }\end{array}$ \\
\hline total_inv_gdp_north & $\begin{array}{l}\text { Total investment flows from OECD to host country, industry and } \\
\text { year }\end{array}$ \\
\hline total_inv_gdp_south & $\begin{array}{l}\text { Total investment flows from non-OECD to host country, industry } \\
\text { and year }\end{array}$ \\
\hline
\end{tabular}


Table A4. Results including shares of FDI

\begin{tabular}{|c|c|c|c|c|}
\hline $\begin{array}{l}\text { Dep. Var.: } \\
\text { GFCF on GDP }\end{array}$ & $\begin{array}{l}\text { (1) } \\
\text { share }\end{array}$ & $\begin{array}{l}\text { (2) } \\
\text { share }\end{array}$ & $\begin{array}{l}\text { (3) } \\
\text { share }\end{array}$ & $\begin{array}{l}(4) \\
\text { share }\end{array}$ \\
\hline share & $\begin{array}{l}0.1182^{* * *} \\
{[0.042]}\end{array}$ & & & \\
\hline share_production & & $\begin{array}{l}0.4538^{* *} \\
{[0.177]}\end{array}$ & & \\
\hline share_trade & & $\begin{array}{l}-0.0186 \\
{[0.048]}\end{array}$ & & \\
\hline share_north & & & $\begin{array}{l}0.1835^{* * *} \\
{[0.063]}\end{array}$ & \\
\hline share_south & & & & $\begin{array}{l}0.0019 \\
{[0.042]}\end{array}$ \\
\hline Constant & $\begin{array}{l}0.3687^{* * *} \\
{[0.051]}\end{array}$ & $\begin{array}{l}0.3688^{* * *} \\
{[0.051]}\end{array}$ & $\begin{array}{l}0.3699 * * * \\
{[0.051]}\end{array}$ & $\begin{array}{l}0.3639^{* * *} \\
{[0.050]}\end{array}$ \\
\hline Observations & 3,999 & 3,999 & 3,999 & 3,999 \\
\hline R-squared & 0.269 & 0.270 & 0.270 & 0.268 \\
\hline 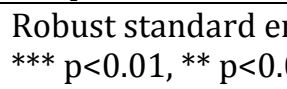 & $\begin{array}{l}\text { s in brackets } \\
{ }^{2} \mathrm{p}<0.1\end{array}$ & & & \\
\hline
\end{tabular}

Table A5. Results including alternative sets of fixed effects

\begin{tabular}{|c|c|c|c|c|c|c|c|c|}
\hline $\begin{array}{l}\text { Dep. Var.: } \\
\text { GFCF on GDP }\end{array}$ & (1) & (2) & (3) & (4) & (5) & (6) & (7) & (8) \\
\hline n_fdi & $\begin{array}{l}0.0008^{*} \\
{[0.000]}\end{array}$ & & & & $\begin{array}{l}0.0017^{* * *} \\
{[0.000]}\end{array}$ & & & \\
\hline n_fdi_production & & $\begin{array}{l}0.0000 \\
{[0.000]}\end{array}$ & & & & $\begin{array}{l}0.0038^{* * *} \\
{[0.001]}\end{array}$ & & \\
\hline n_fdi_trade & & $\begin{array}{l}0.0005 \\
{[0.000]}\end{array}$ & & & & $\begin{array}{l}-0.0002 \\
{[0.001]}\end{array}$ & & \\
\hline n_fdi_north & & & $\begin{array}{l}0.0009 * \\
{[0.001]}\end{array}$ & & & & $\begin{array}{l}0.0020^{* * *} \\
{[0.000]}\end{array}$ & \\
\hline n_fdi_south & & & & $\begin{array}{l}0.0010 \\
{[0.001]}\end{array}$ & & & & $\begin{array}{l}0.0004 \\
{[0.002]}\end{array}$ \\
\hline $\begin{array}{l}\text { Country-industry } \\
\text { effects }\end{array}$ & Y & Y & Y & $\mathrm{Y}$ & $\mathrm{N}$ & $\mathrm{N}$ & $\mathrm{N}$ & $\mathrm{N}$ \\
\hline Year effects & Y & Y & Y & Y & $\mathrm{N}$ & $\mathrm{N}$ & $\mathrm{N}$ & $\mathrm{N}$ \\
\hline Country-year effects & $\mathrm{N}$ & $\mathrm{N}$ & $\mathrm{N}$ & $\mathrm{N}$ & Y & Y & Y & Y \\
\hline Industry-year effects & $\mathrm{N}$ & $\mathrm{N}$ & $\mathrm{N}$ & $\mathrm{N}$ & Y & Y & Y & Y \\
\hline Constant & $\begin{array}{l}0.0539^{* * *} \\
{[0.005]}\end{array}$ & $\begin{array}{l}0.0561^{* * *} \\
{[0.005]}\end{array}$ & $\begin{array}{l}0.0540^{* * *} \\
{[0.005]}\end{array}$ & $\begin{array}{l}0.0560^{* * *} \\
{[0.005]}\end{array}$ & $\begin{array}{l}0.0467^{* * *} \\
{[0.012]}\end{array}$ & $\begin{array}{l}0.0479^{* * *} \\
{[0.012]}\end{array}$ & $\begin{array}{l}0.0467^{* * *} \\
{[0.012]}\end{array}$ & $\begin{array}{l}0.0573^{* * *} \\
{[0.012]}\end{array}$ \\
\hline Observations & 4,410 & 4,410 & 4,410 & 4,410 & 4,410 & 4,410 & 4,410 & 4,410 \\
\hline R-squared & 0.874 & 0.874 & 0.874 & 0.874 & 0.311 & 0.312 & 0.311 & 0.310 \\
\hline
\end{tabular}

Robust standard errors in brackets

${ }^{* * *} \mathrm{p}<0.01,{ }^{* *} \mathrm{p}<0.05{ }^{*} \mathrm{p}<0.1$ 
Table A6. Results including lagged levels of FDI

\begin{tabular}{|c|c|c|c|}
\hline $\begin{array}{l}\text { Dep. Var:: } \\
\text { GFCF on GDP }\end{array}$ & (1) & (2) & (3) \\
\hline L.n_fdi & $\begin{array}{l}0.0020^{* * *} \\
{[0.000]}\end{array}$ & & \\
\hline L2.n_fdi & & $\begin{array}{l}0.0022^{* * *} \\
{[0.000]}\end{array}$ & \\
\hline L3.n_fdi & & & $\begin{array}{l}0.0028^{* * *} \\
{[0.001]}\end{array}$ \\
\hline Constant & $\begin{array}{l}0.3474^{* * *} \\
{[0.056]}\end{array}$ & $\begin{array}{l}0.3218^{* * *} \\
{[0.055]}\end{array}$ & $\begin{array}{l}0.2611^{* * *} \\
{[0.045]}\end{array}$ \\
\hline Observations & 3,172 & 2,593 & 2,052 \\
\hline R-squared & 0.270 & 0.286 & 0.309 \\
\hline
\end{tabular}

Note: All the specifications include country-, industry- and year-effects 


\begin{abstract}
APPENDIX B
Definition of Gross fixed capital formation in UNIDO INDSTAT:

Gross fixed capital formation refers to the value of purchases and own-account construction of fixed assets during the reference year less the value of corresponding sales. The fixed assets covered are those (whether new or used) with a productive life of one year or more. These assets, which are intended for the use of the establishment, include fixed assets made by the establishment's own labour force for its own use. Major additions, alterations and improvements to existing assets, which extend their normal economic life or raise their productivity, are also included.
\end{abstract}

New fixed assets include all those that have not been previously used in the country. Thus, newly imported fixed assets are considered new whether or not used before they were imported. Used fixed assets include all those that have been previously used within the country. Transactions in fixed assets include: (a) land; (b) buildings, other construction and land improvements; (c) transport equipment; and (d) machinery and other equipment. Countries that have started implementation of recent recommendations for industrial statistics might have extended the coverage of fixed assets to products of research and development, computer software and database and other intellectual property products.

Assets acquired from others are valued at purchasers' prices, which cover all costs directly connected with the acquisition and installation of the items for use. In principle, assets produced on own account are also valued in this manner. However, it may frequently be necessary to value such own-account production at explicit cost, including any imputations that may be required in respect of the employed own-account labour. Assets produced by one establishment of a multi-establishment enterprise for the use of another establishment of the same enterprise should be valued by the receiving establishment as though purchased from outside the enterprise. Sales of assets should be valued at the actual amounts realized rather than at book values. 